\title{
Photochemical Study of Tris(benzotriazol-1-yl)methane
}

\author{
Dmitry A. Androsov and Douglas C. Neckers* \\ Center for Photochemical Sciences, Bowling Green State University, \\ Bowling Green, Ohio 43403, USA \\ neckers@photo.bgsu.edu
}

\section{List of content}

Page number

${ }^{1} \mathrm{H}$ spectrum of tris(benzotrizol-1-yl)methane (1) in $\mathrm{CDCl}_{3}$

${ }^{13} \mathrm{C}$ spectrum of tris(benzotrizol-1-yl)methane (1) in $\mathrm{CDCl}_{3}$

S5

MS-DIP of tris(benzotrizol-1-yl)methane (1)

S6

GCMS of tris(benzotrizol-1-yl)methane (1)

S7

${ }^{1} \mathrm{H}$ spectrum of 1-benzotryazol-1-yl-methylidene]-biphenyl-2-yl-amine (2) in $\mathrm{CDCl}_{3}$

S8

${ }^{13} \mathrm{C}$ spectrum of 1-benzotryazol-1-yl-methylidene]-biphenyl-2-yl-amine (2) in $\mathrm{CD}_{3} \mathrm{CN}$

S9

GCMS of 1-benzotryazol-1-yl-methylidene]-biphenyl-2-yl-amine (2)

$\mathbf{S 1 0}$

LCMS of 1-benzotryazol-1-yl-methylidene]-biphenyl-2-yl-amine (2)

S11

${ }^{1} \mathrm{H}$ spectrum of phenantridine in $(3) \mathrm{CDCl}_{3}$

S12

${ }^{13} \mathrm{C}$ spectrum of phenantridine in $(3) \mathrm{CDCl}_{3}$

S13 
${ }^{1} \mathrm{H}$ spectrum of benzotriazole (4) in $\mathrm{CDCl}_{3}$

${ }^{1} \mathrm{H}$ spectrum $\left(\mathrm{CDCl}_{3}\right)$ of benzotriazole (4) in $\mathrm{C}_{6} \mathrm{H}_{6}\left(\mathrm{C}_{0}=4.2 \times 10^{-3} \mathrm{~mol} / \mathrm{l}\right)$

after $8 \mathrm{~h}$ of irradiation at $300 \mathrm{~nm}$. The product is 2-aminobipenyl (6)

GSMC of benzotriazole (4) in $\mathrm{C}_{6} \mathrm{H}_{6}\left(\mathrm{C}_{0}=4.2 \times 10^{-3} \mathrm{~mol} / \mathrm{l}\right)$ after $8 \mathrm{~h}$ of irradiation

at $300 \mathrm{~nm}$. The product is 2-aminobipenyl (6)

${ }^{1} \mathrm{H}$ spectrum of biphenyl-2-yl-methylamine (7) in $\mathrm{CDCl}_{3}$

${ }^{13} \mathrm{C}$ spectrum of biphenyl-2-yl-methylamine (7) in $\mathrm{CDCl}_{3}$

GCMS of biphenyl-2-yl-methylamine (7) in $\mathrm{CDCl}_{3}$

S21

${ }^{1} \mathrm{H}-\mathrm{NMR}$ of tris(1-benzotriazolyl)methane (1) in $\mathrm{C}_{6} \mathrm{D}_{6}$ at $\lambda=254 \mathrm{~nm}$ after $8 \mathrm{~h}$

GCMS monitoring of tris(1-benzotriazolyl)methane (1) decomposition in $\mathrm{C}_{6} \mathrm{H}_{6}$ at $\lambda=300 \mathrm{~nm}$

MS of 2-aminobiphenyl-d6 (6')

S24

MS of intermediate"imine"- $d 5$ (2')

MS of phenantridine- $d 4$ (3')

UV spectra of tris(1-benzotriazolyl)methane (1) and products

of its photodecomposition in cyclohexane

${ }^{1} \mathrm{H}-\mathrm{NMR}$ monitoring of tris(1-benzotriazolyl)methane (1) photodecomposition in $\mathrm{C}_{6} \mathrm{D}_{6}$

$\left(\mathrm{C}_{0}=4.09 \times 10^{-3} \mathrm{~mol} / \mathrm{l}\right)$ at $\lambda=254 \mathrm{~nm}$ 
${ }^{1} \mathrm{H}-\mathrm{NMR}$ monitoring of tris(1-benzotriazolyl)methane (1) photodecomposition in $\mathrm{C}_{6} \mathrm{D}_{6}$

$\left(\mathrm{C}_{0}=4.09 \times 10^{-3} \mathrm{~mol} / \mathrm{l}\right)$ at $\lambda=300 \mathrm{~nm}$

UV spectra of tris-(1-benzotriazolyl)methane (1) and benzotriazole (4) in methanol

S30

Irradiation of tris(1-benzotriazolyl)methane (1) ethanol at $300 \mathrm{~nm}$. UV monitoring

S31

Irradiation of tris(1-benzotriazolyl)methane (1) ethanol at $254 \mathrm{~nm}$. UV monitoring

S32

General methods and materials

S33

-S3- 


\section{${ }^{1} \mathrm{H}$ spectrum of tris(benzotrizol-1-yl)methane (1) in $\mathrm{CDCl}_{3}$.}
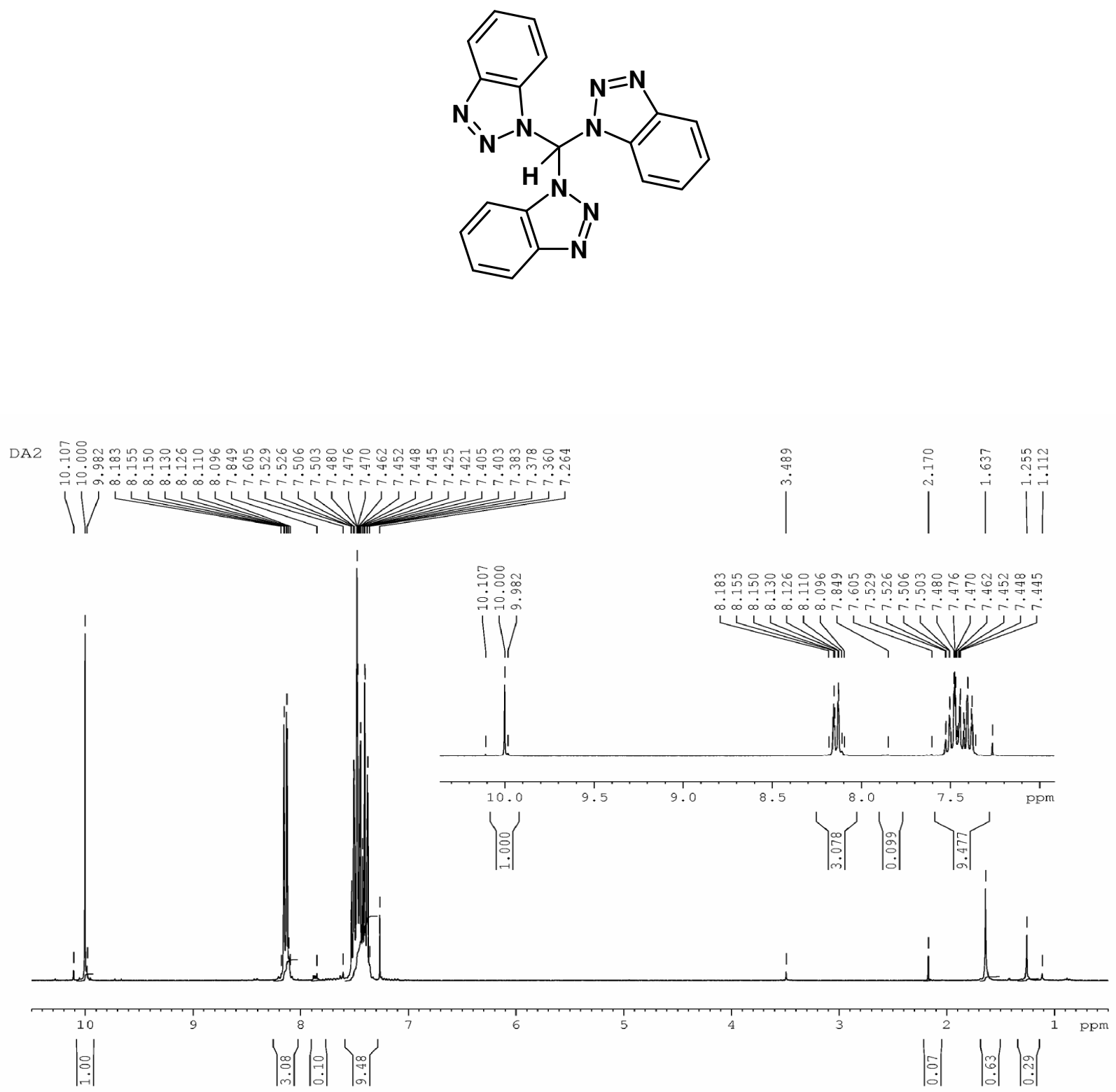


\section{${ }^{13} \mathrm{C}$ spectrum of tris(benzotrizol-1-yl)methane (1) in $\mathrm{CDCl}_{3}$.}
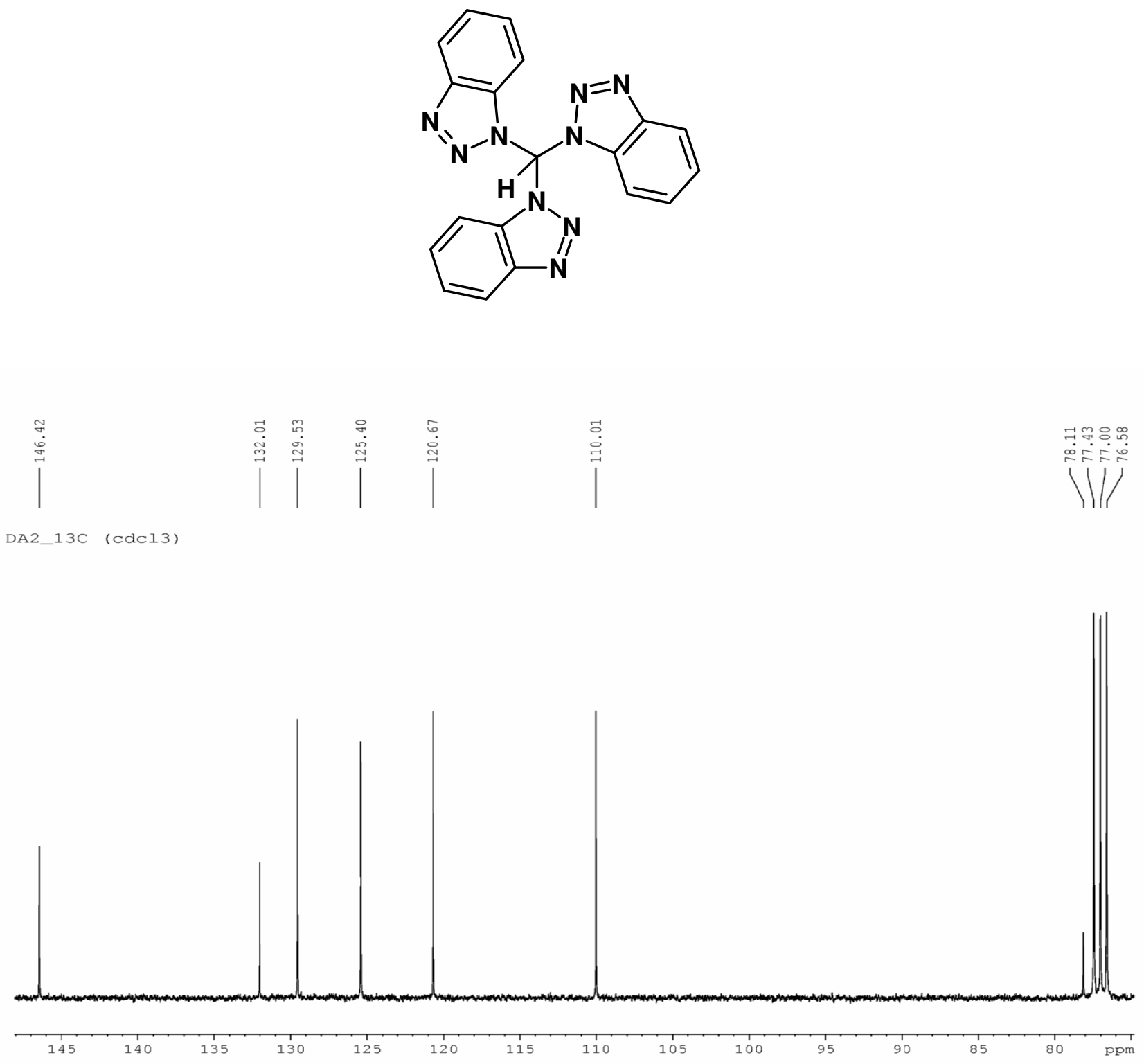
MS-DIP of tris(benzotrizol-1-yl)methane (1).
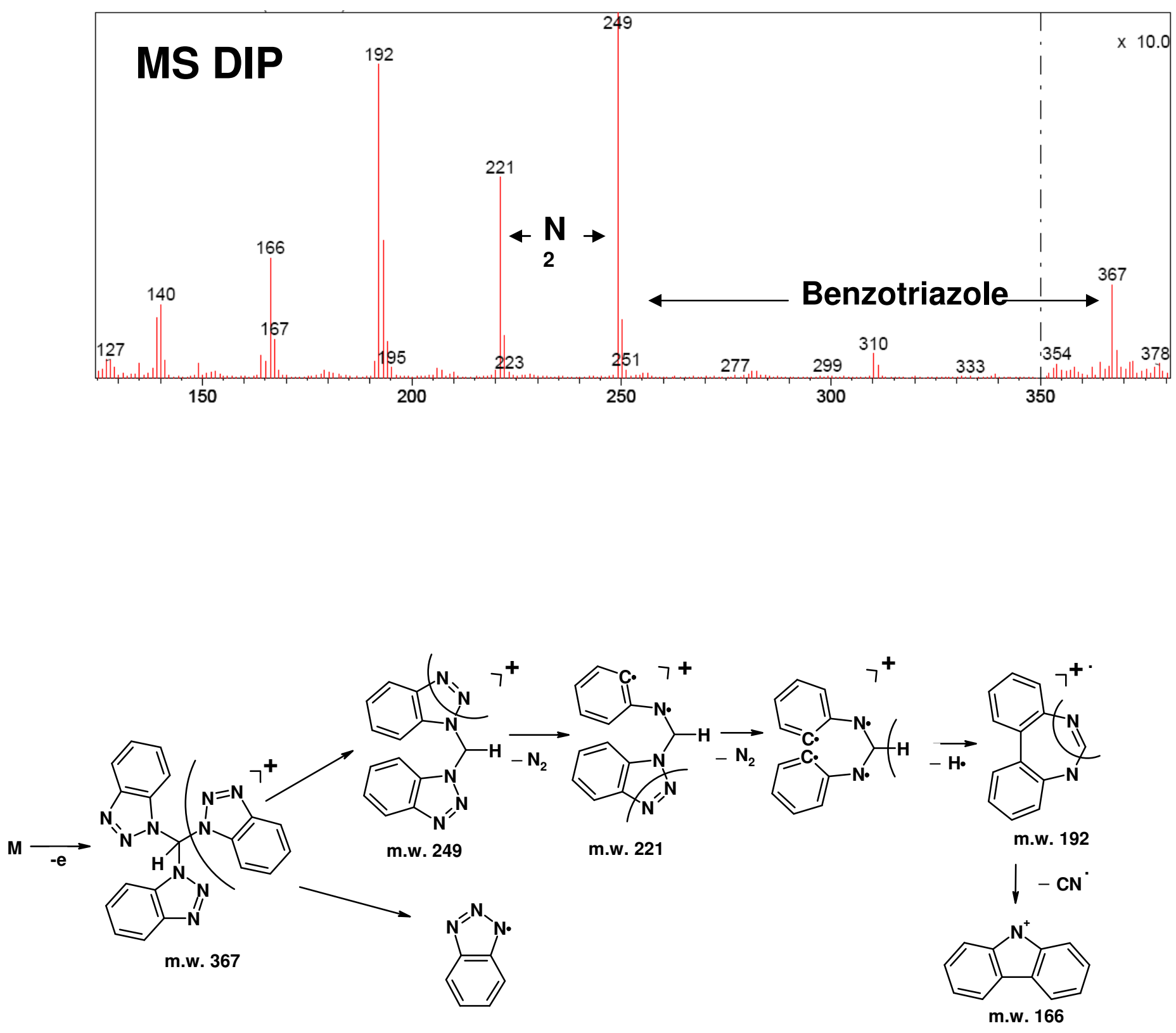


\section{GCMS of tris(benzotrizol-1-yl)methane (1).}
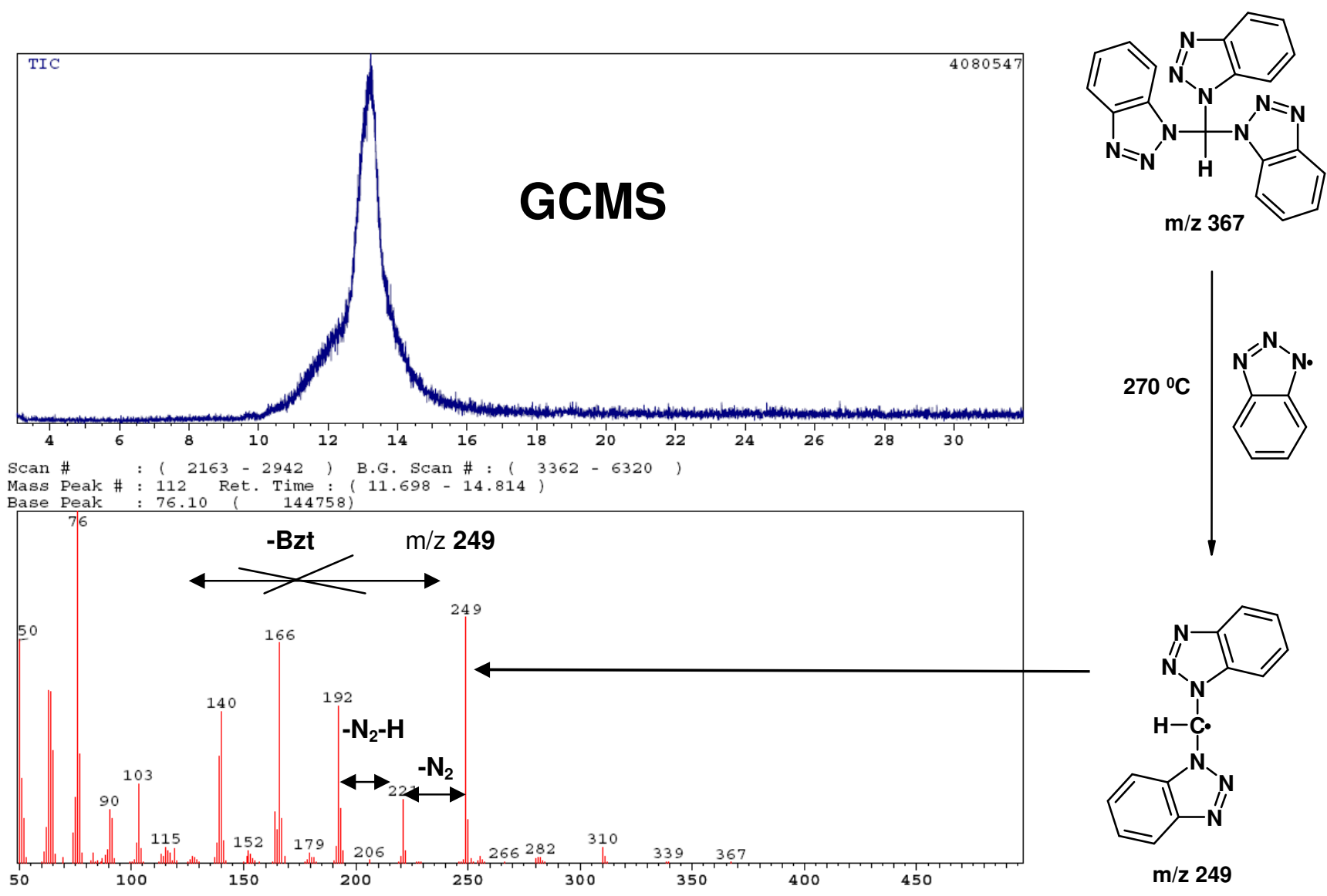


\section{${ }^{1} \mathrm{H}$ spectrum of}

\section{[1-benzotryazol-1-yl-methylidene]-biphenyl-2-yl-amine (2) in $\mathrm{CDCl}_{3}$.}

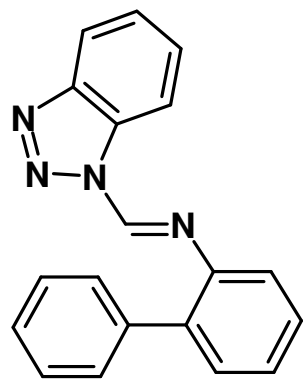

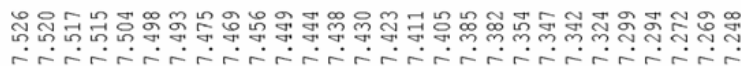

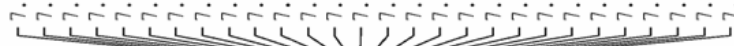

DA17-2_1H (cdcl3)
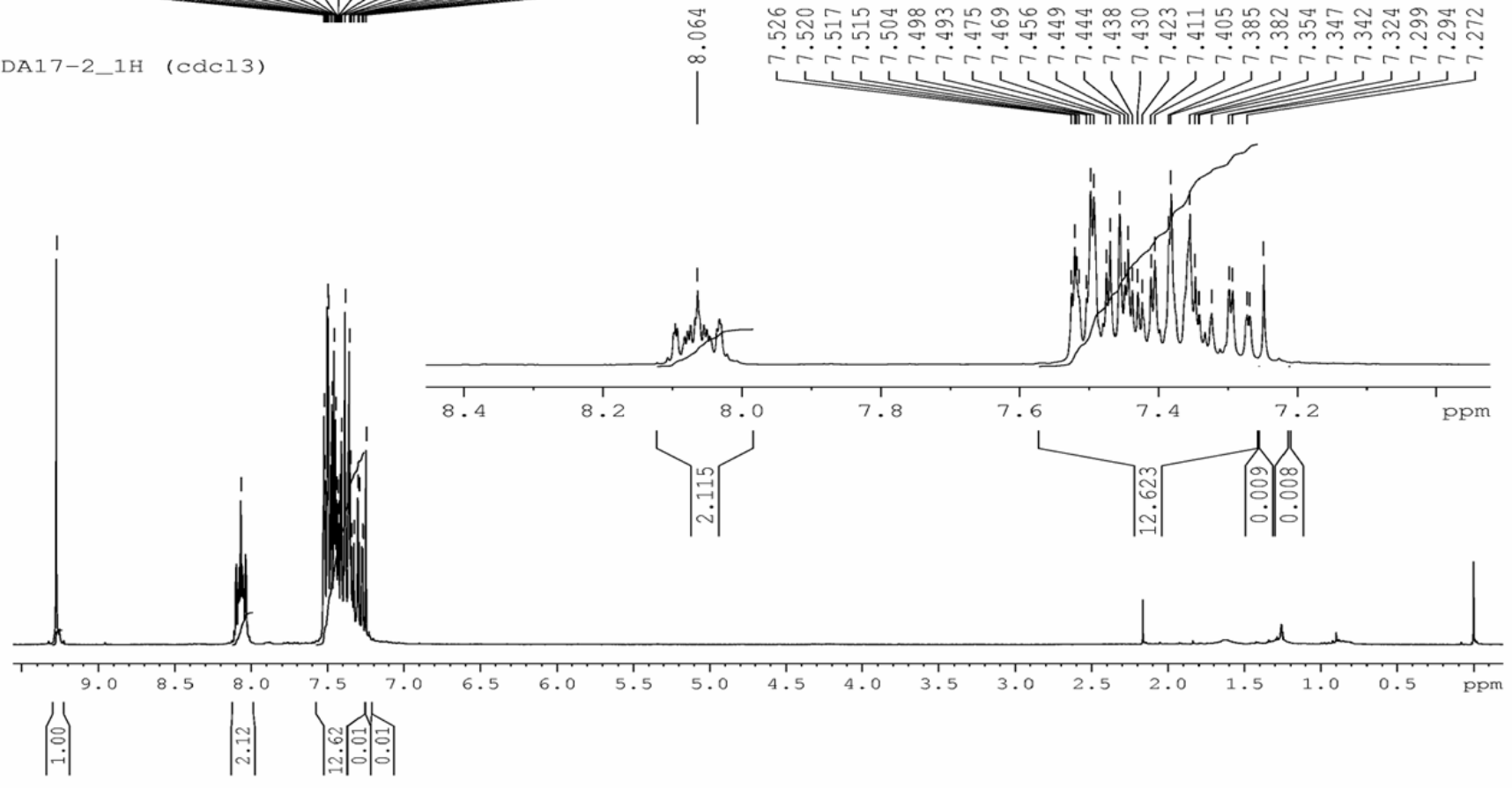


\section{${ }^{13} \mathrm{C}$ spectrum of}

[1-benzotryazol-1-yl-methylidene]-biphenyl-2-yl-amine (2) in $\mathrm{CD}_{3} \mathrm{CN}$.
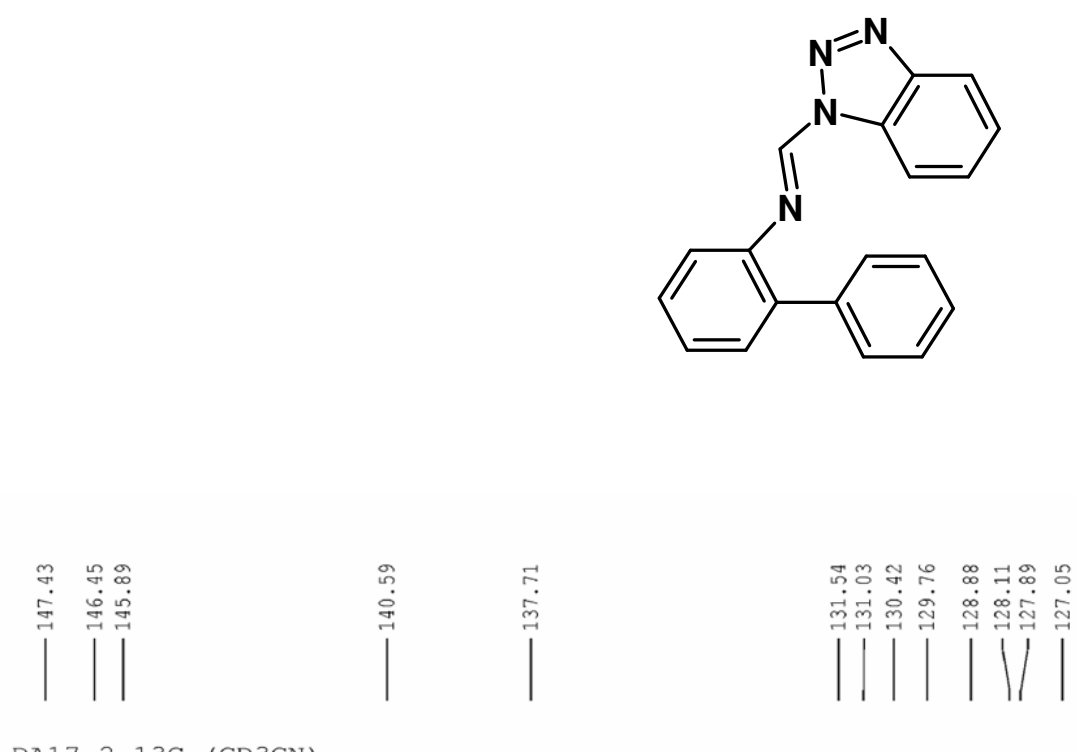

DA17-2_13C (CD $3 C N)$

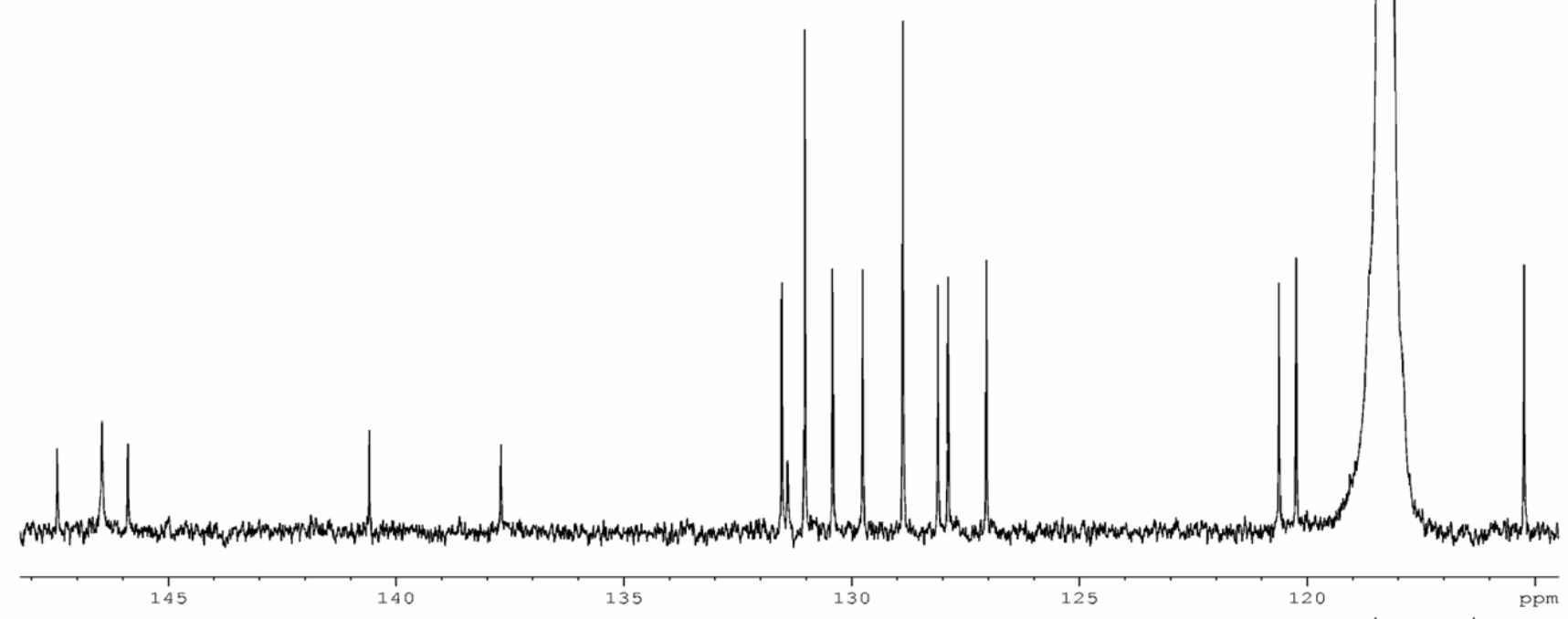

-S9- 
GCMS of [1-benzotryazol-1-yl-methylidene]-biphenyl-2-yl-amine (2).
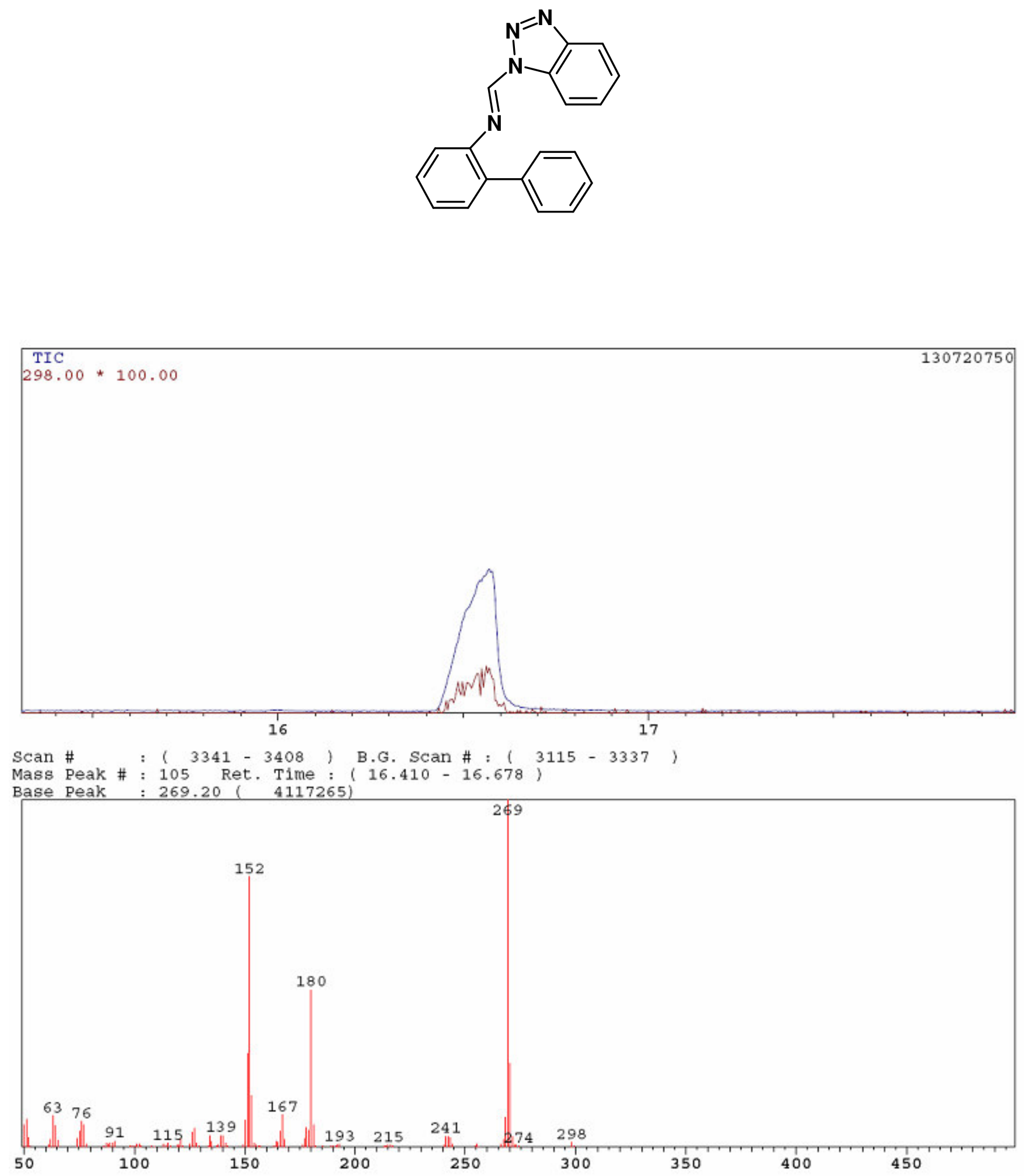

-S10- 
LCMS of [1-benzotryazol-1-yl-methylidene]-biphenyl-2-yl-amine (2).
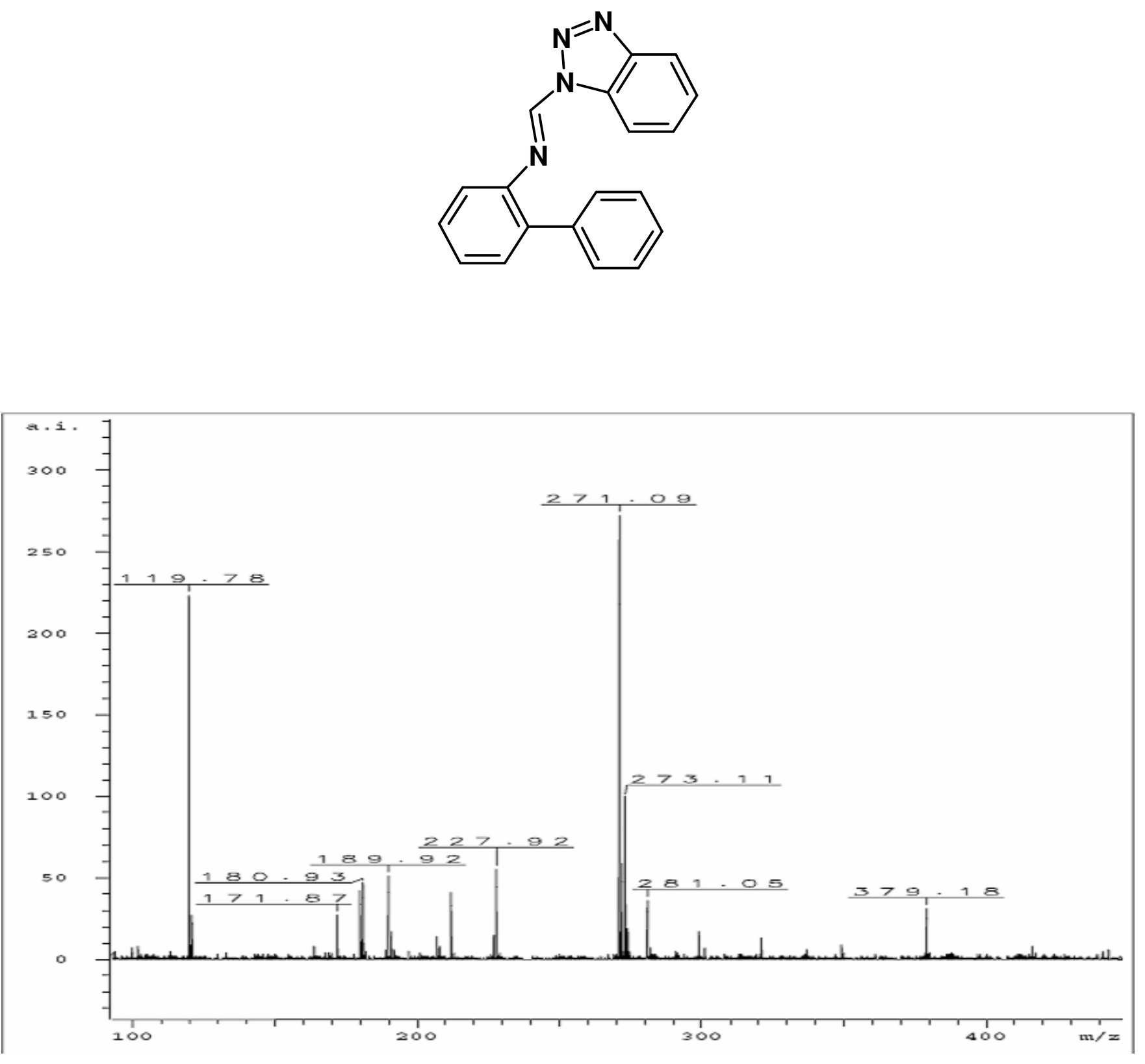


\section{${ }^{1} \mathrm{H}$ spectrum of phenantridine $(3)$ in $\mathrm{CDCl}_{3}$.}
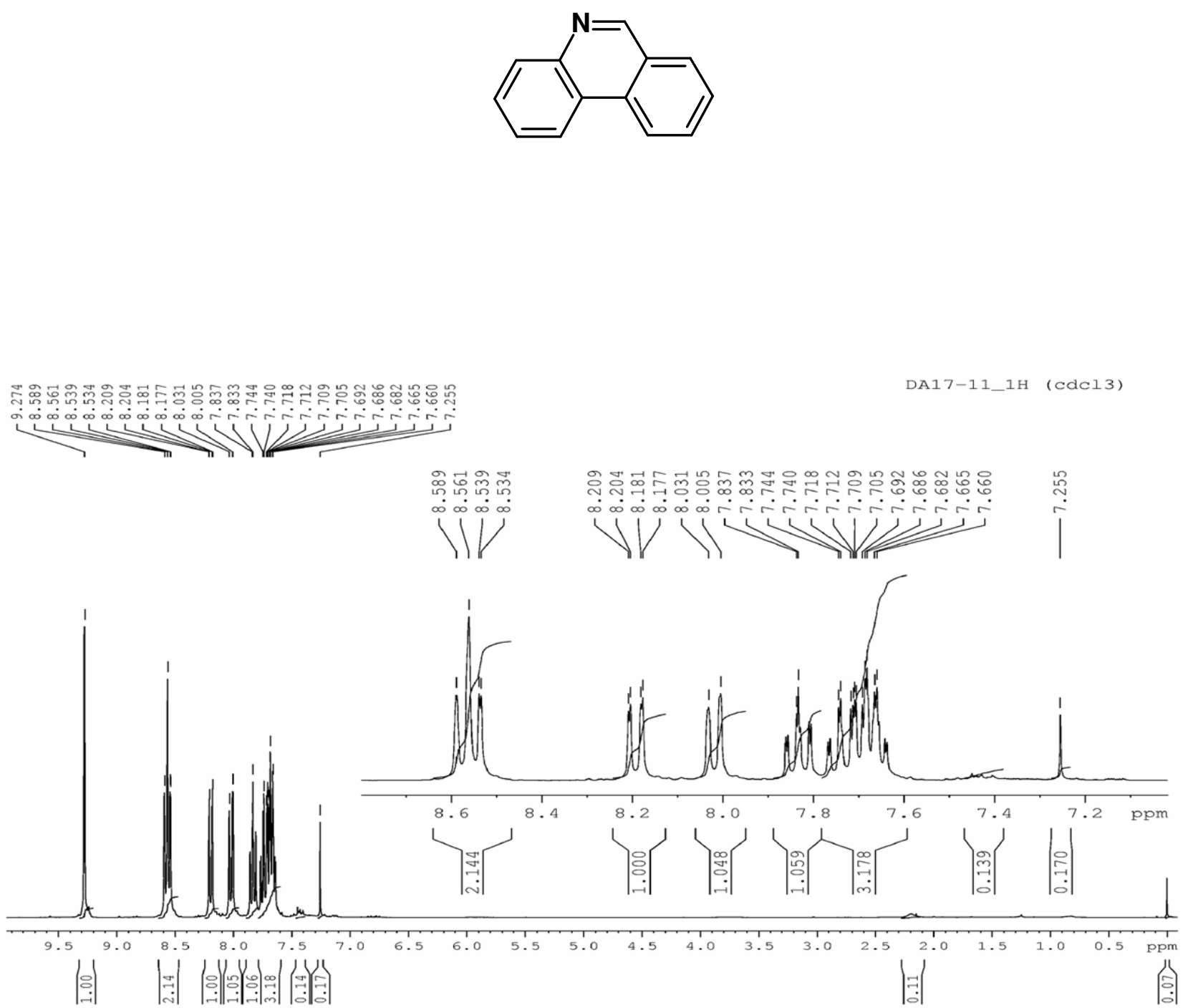


\section{${ }^{13} \mathrm{C}$ spectrum of phenantridine $(3)$ in $\mathrm{CDCl}_{3}$.}
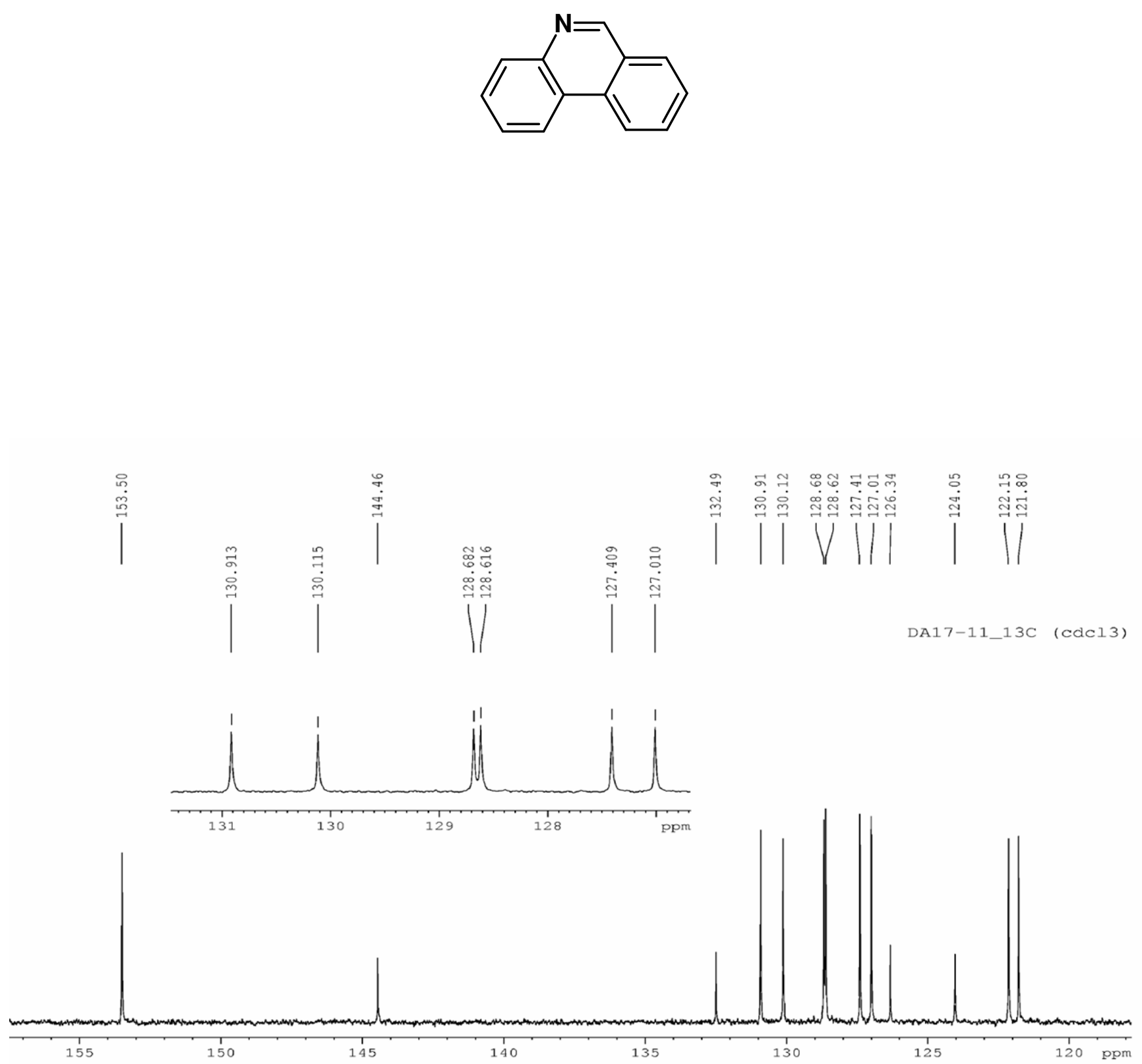


\section{GCMS of phenantridine (3).}

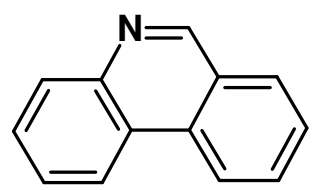

Data : DA.D14 06/03/22 16:46:30

Sample : :17-11

Operator : $J R$

Method File Name : GC300.MET

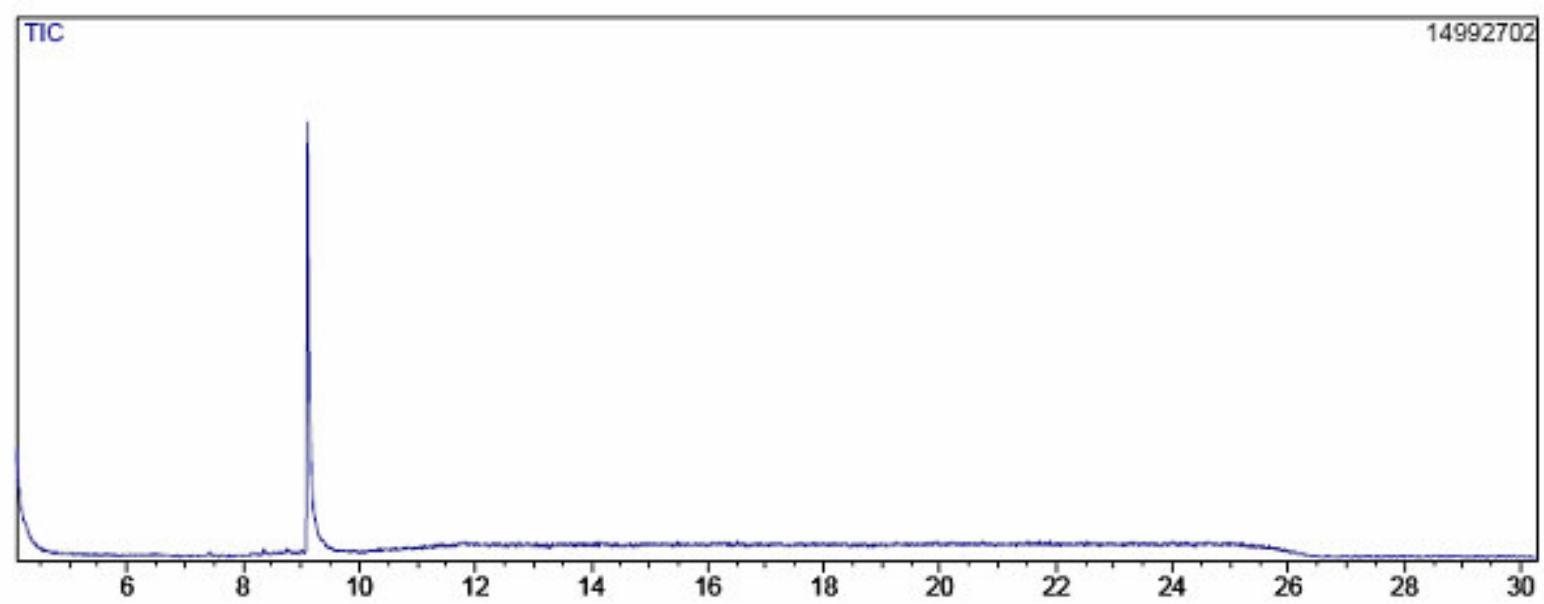

Scan $\# \quad:(1252-1274)$

Mass Peak $\frac{\pi}{\pi}: 167$ Ret. Time : ( $9.101-9.189$ )

Base Peak : 179.10 ( 1803451)

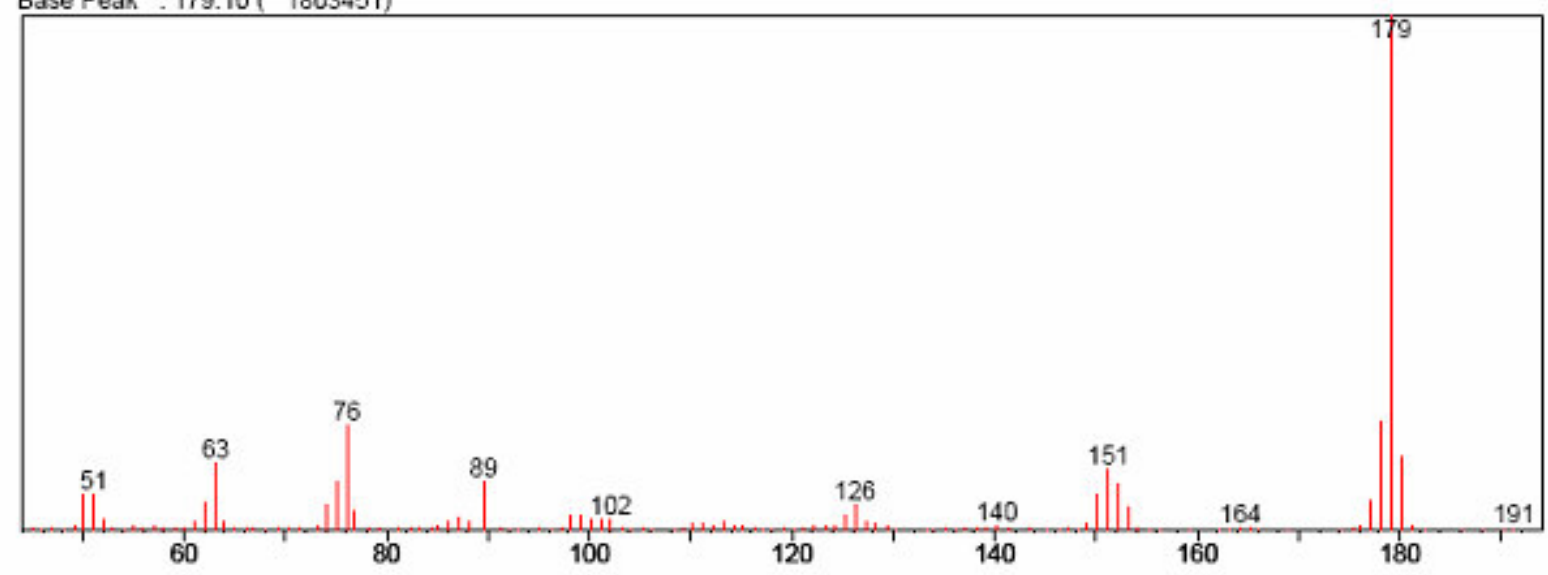

-S14- 


\section{${ }^{1} \mathrm{H}$ spectrum of benzotriazole in $\mathrm{CDCl}_{3}(\mathbf{4})$.}<smiles>c1ccc2[nH]nnc2c1</smiles>

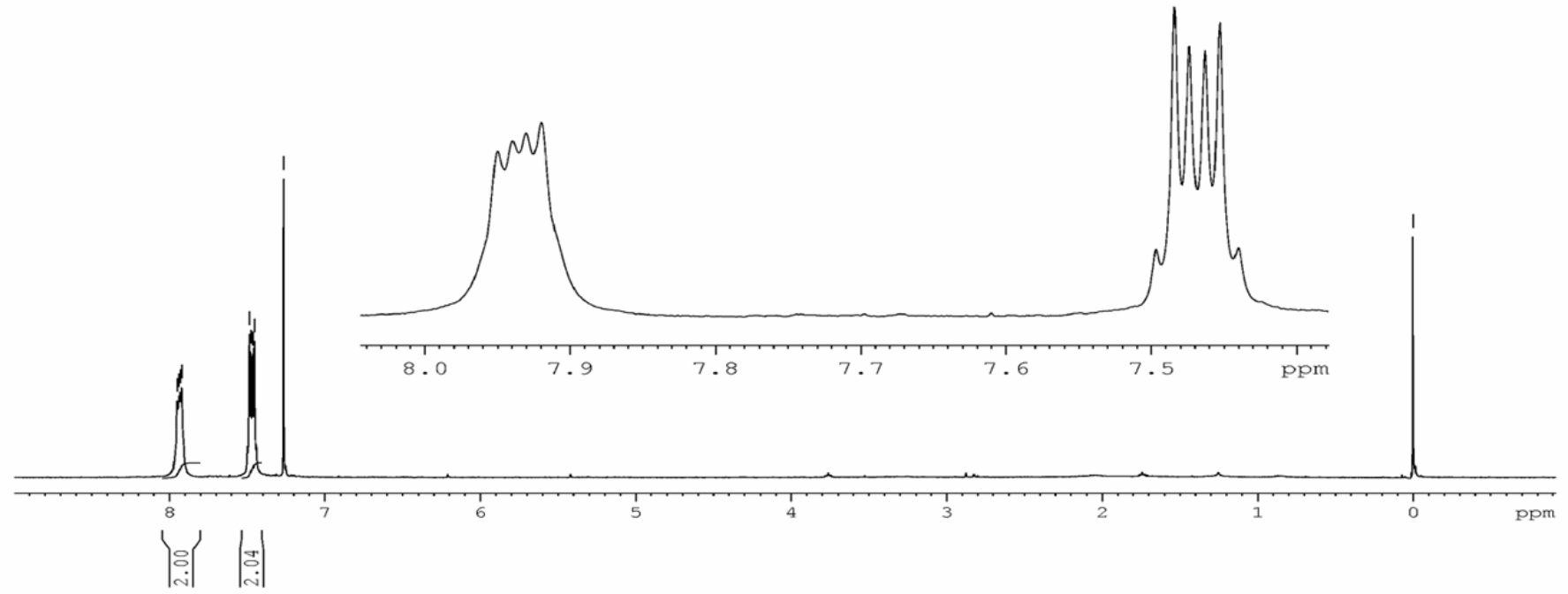


GCMS of benzotriazole (4).<smiles>c1ccc2[nH]nnc2c1</smiles>

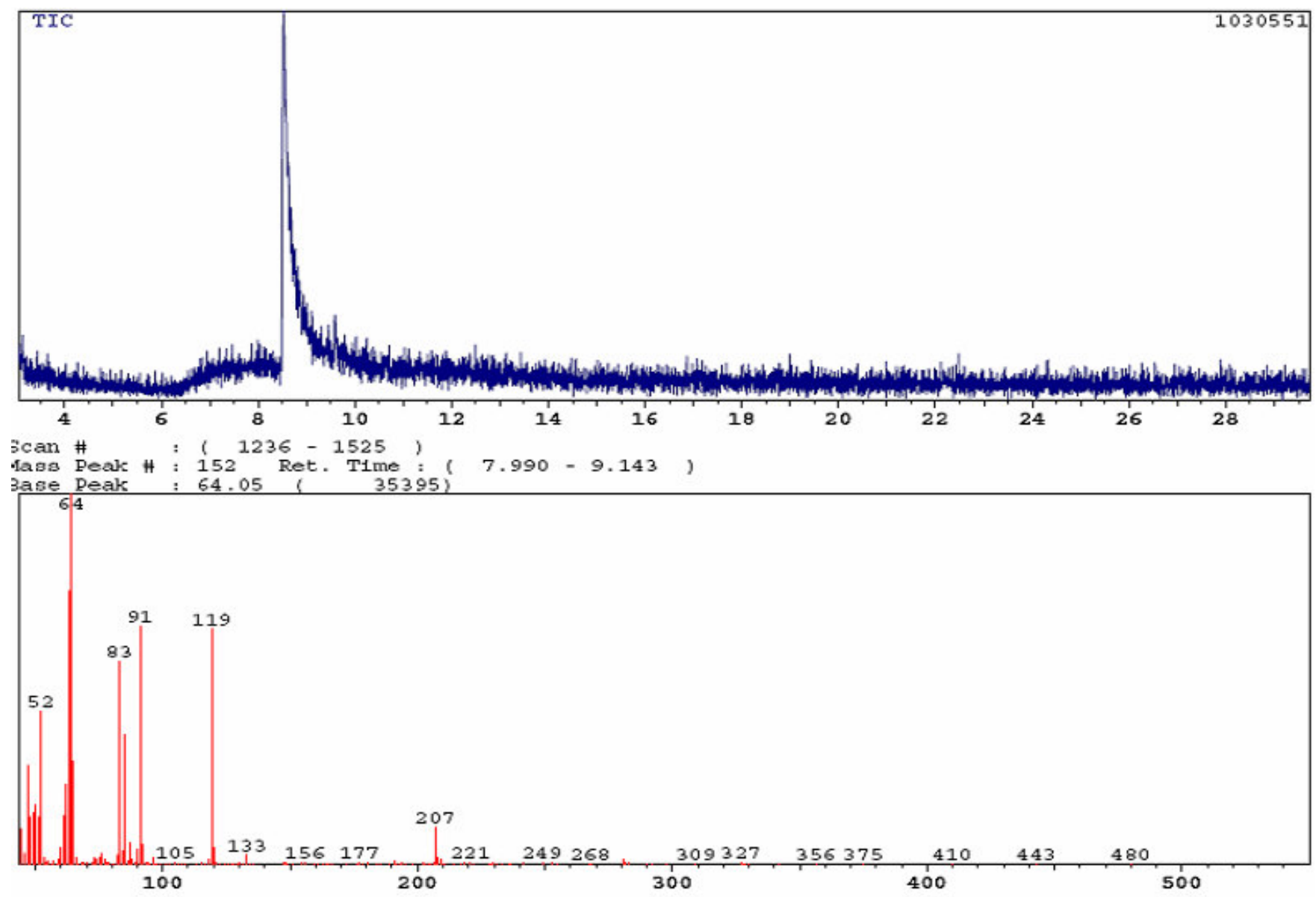


${ }^{1} \mathrm{H}$ spectrum $\left(\mathrm{CDCl}_{3}\right)$ of benzotriazole (4) in $\mathrm{C}_{6} \mathrm{H}_{6}\left(\mathrm{C}_{0}=4.2 \times 10^{-3} \mathrm{~mol} / \mathrm{l}\right)$ after $8 \mathrm{~h}$ of irradiation at $300 \mathrm{~nm}$. The product is 2-aminobipenyl (6).<smiles>Nc1ccccc1-c1ccccc1</smiles>
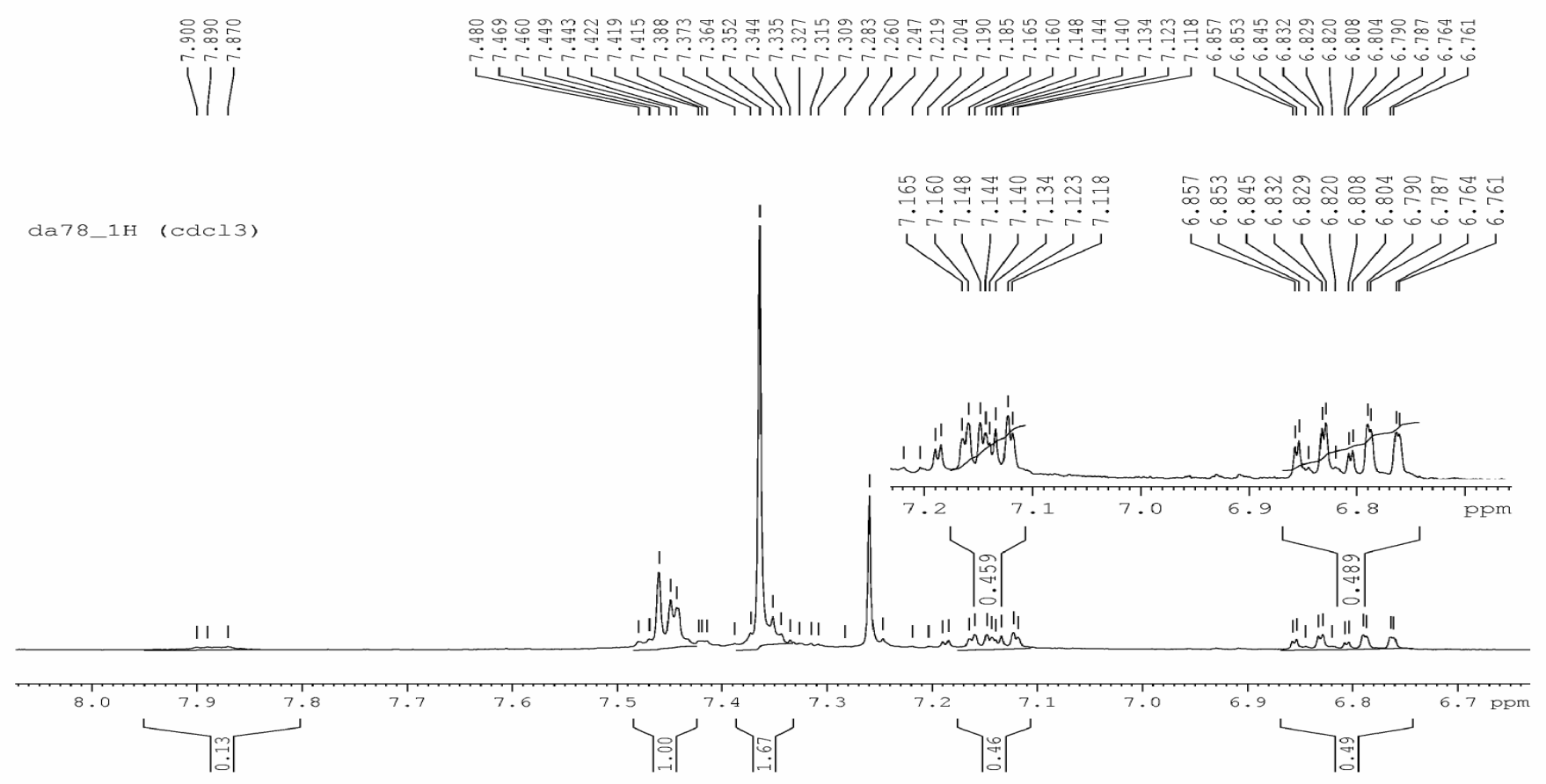
GSMC of benzotriazole (4) in $\mathrm{C}_{6} \mathrm{H}_{6}\left(\mathrm{C}_{0}=4.2 \times 10^{-3} \mathrm{~mol} / \mathrm{l}\right)$ after $8 \mathrm{~h}$ of irradiation at $300 \mathrm{~nm}$. The product is 2 -aminobipenyl (6).
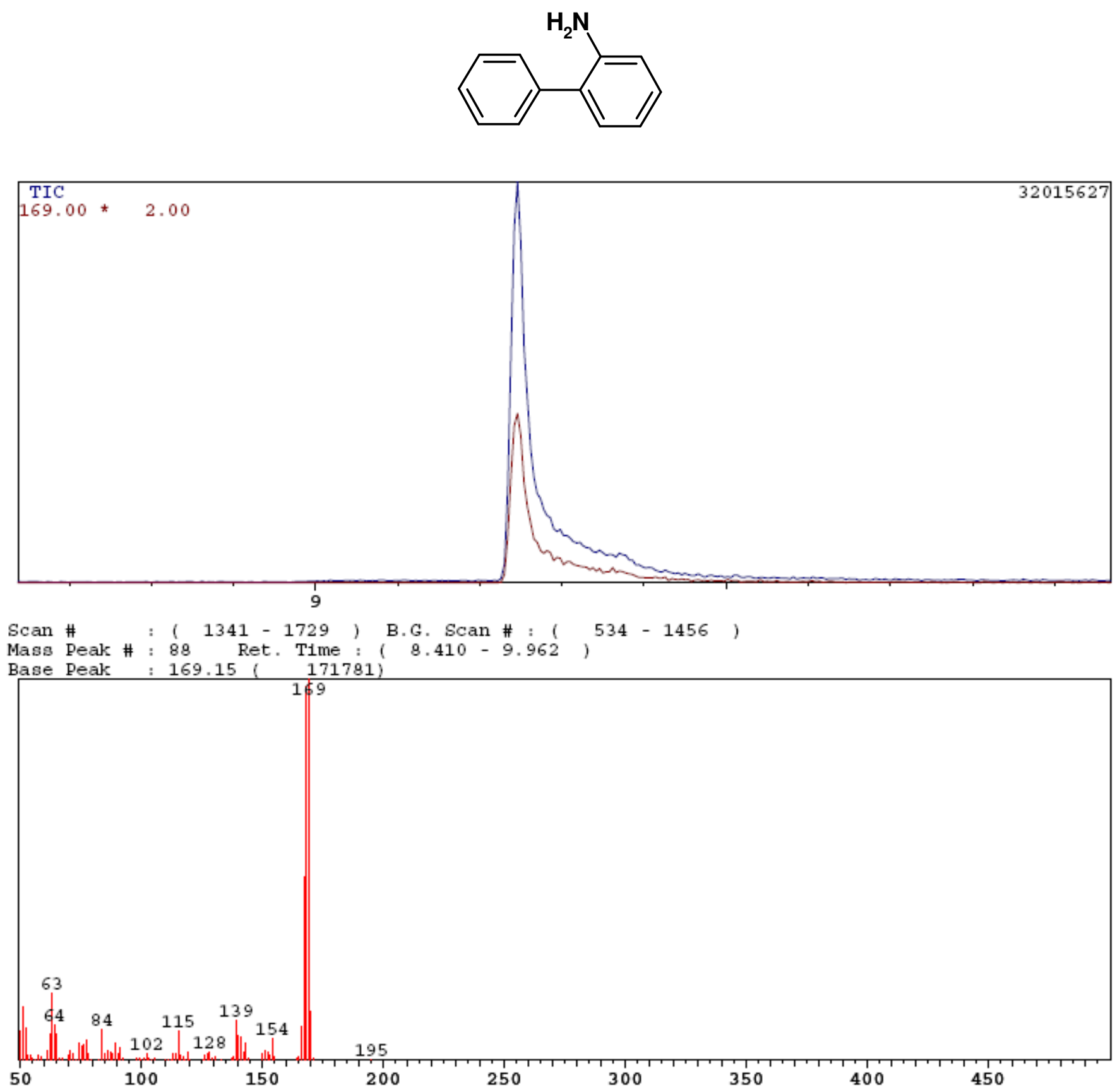

-S18- 
${ }^{1} \mathrm{H}$ spectrum of biphenyl-2-yl-methylamine (7) in $\mathrm{CDCl}_{3}$.
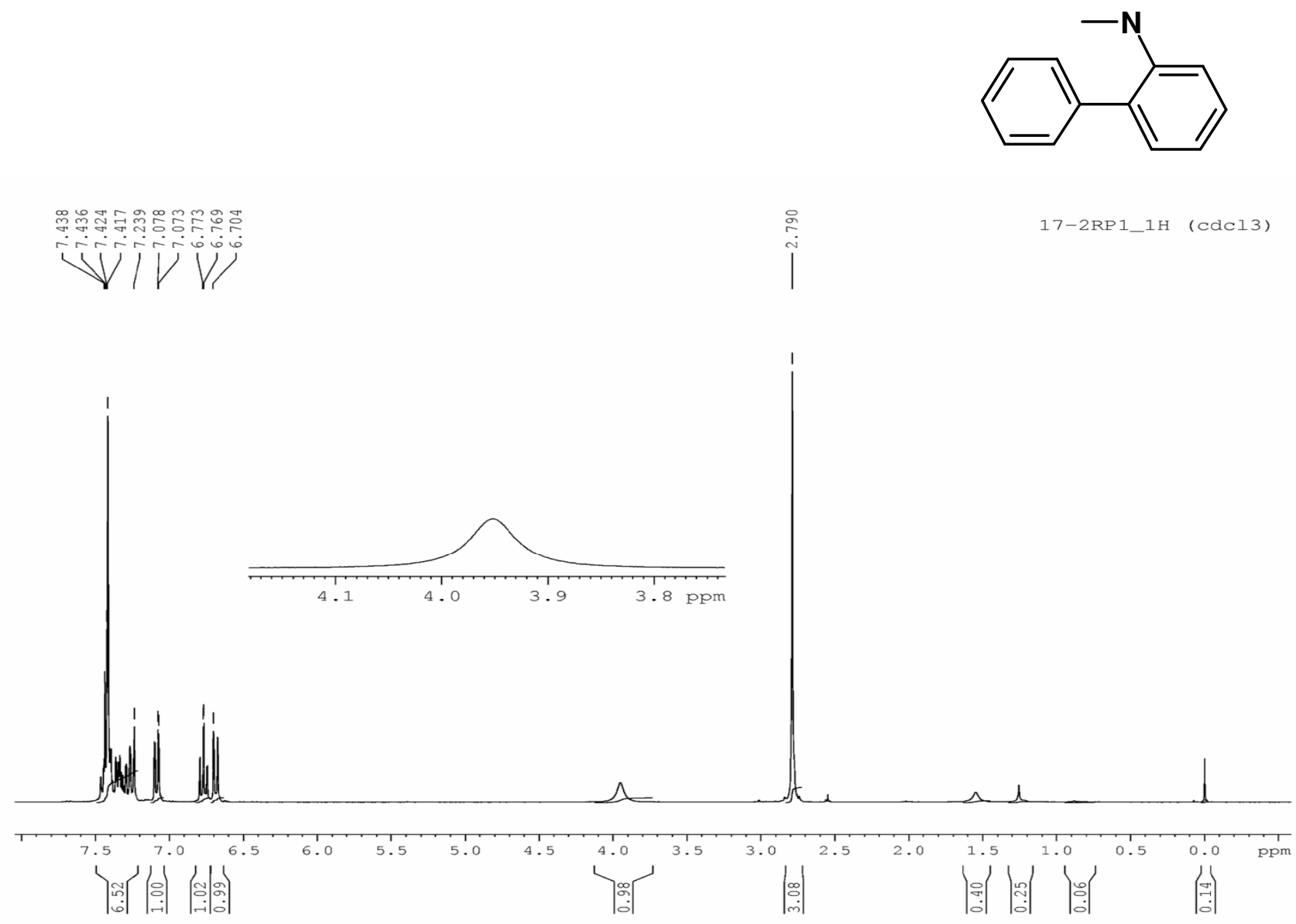

-S19. 
${ }^{13} \mathrm{C}$ spectrum of biphenyl-2-yl-methylamine (7) in $\mathrm{CDCl}_{3}$.
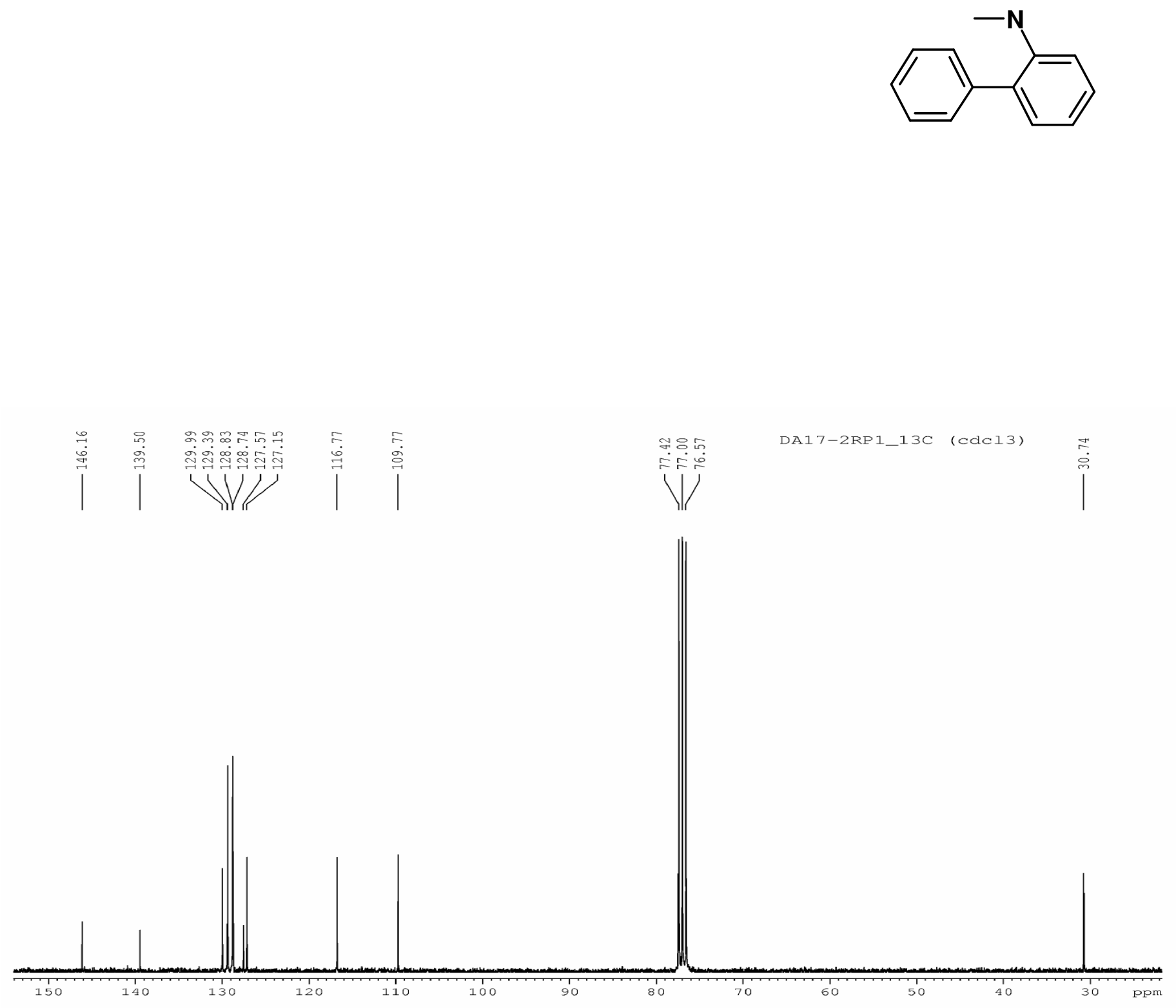


\section{GCMS of biphenyl-2-yl-methylamine (7) in $\mathrm{CDCl}_{3}$.}

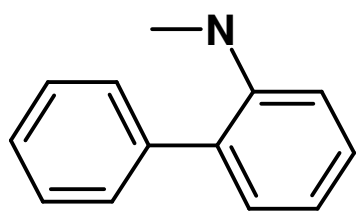

m.w. 183

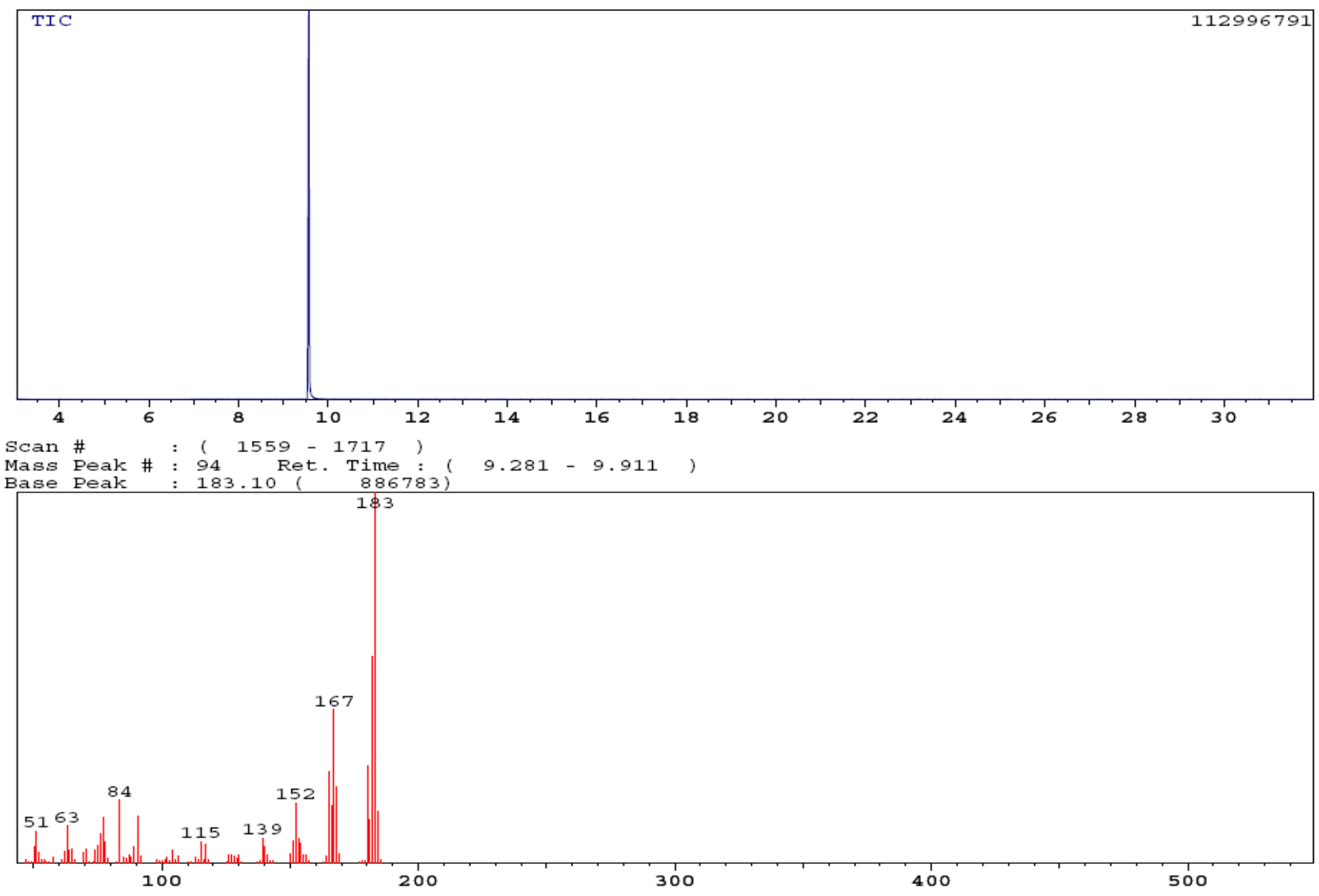




\section{${ }^{1} \mathrm{H}$-NMR of tris(1-benzotriazolyl)methane (1) in $\mathrm{C}_{6} \mathrm{D}_{6}$ at $\lambda=254 \mathrm{~nm}$ after 8}

h.

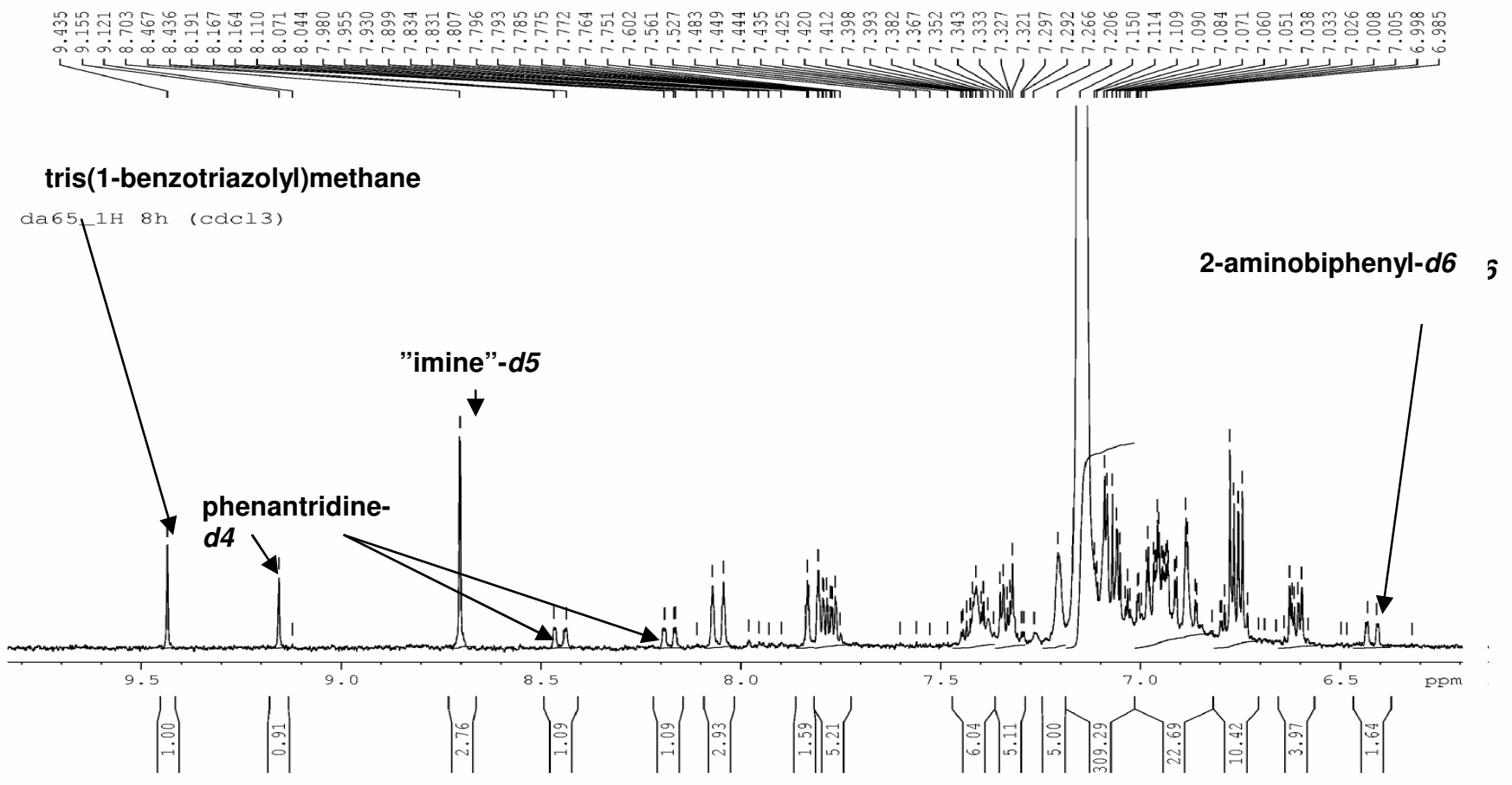


GCMS monitoring of tris(1-benzotriazolyl)methane (1) decomposition in $\mathrm{C}_{6} \mathrm{H}_{6}$ at $\lambda=300 \mathrm{~nm}$.

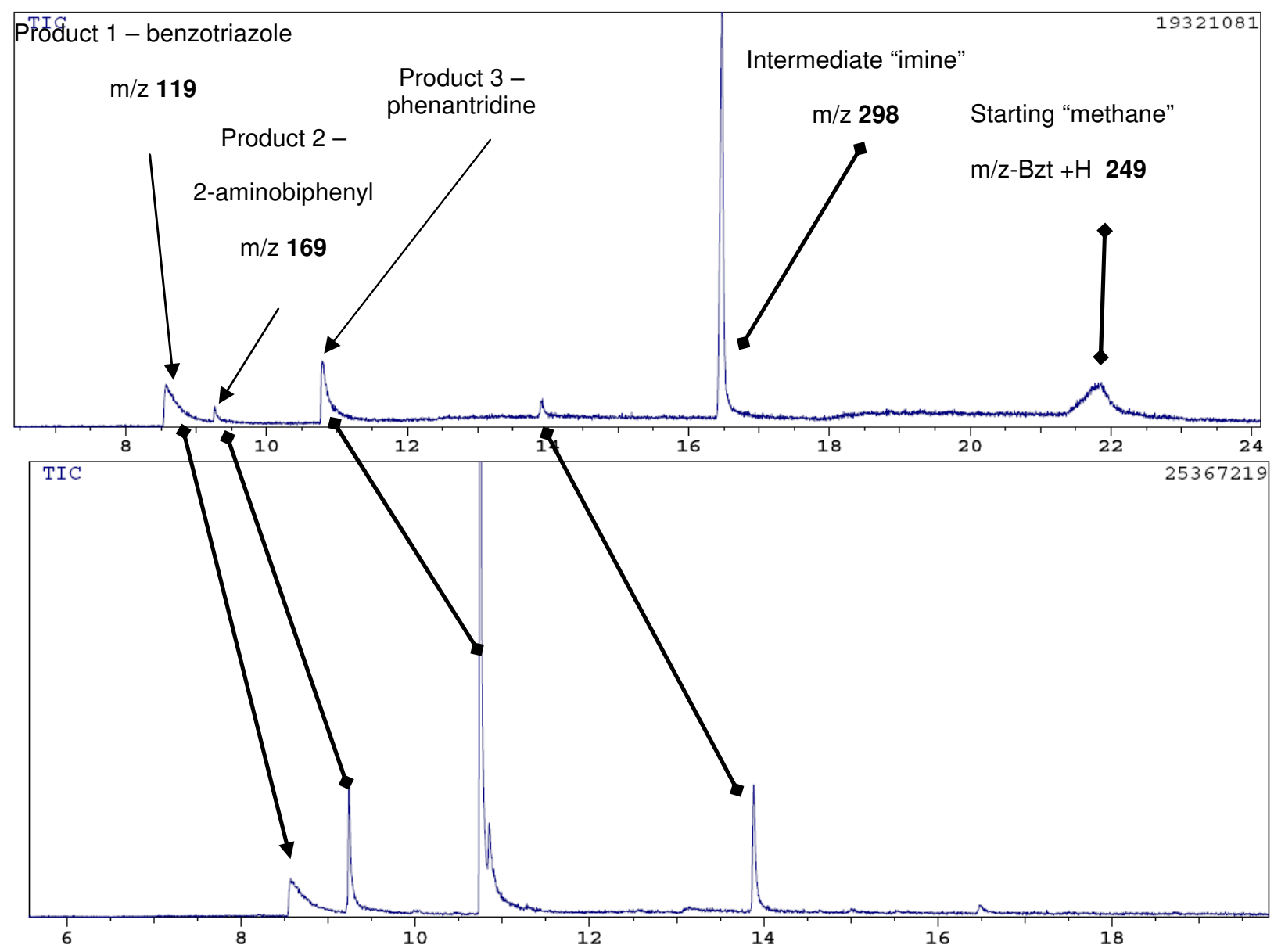

$1 \mathrm{~h}$

$27 \mathrm{~h}$ 


\section{MS of 2-aminobiphenyl- $d 6\left(\mathbf{6}^{\prime}\right)$.}

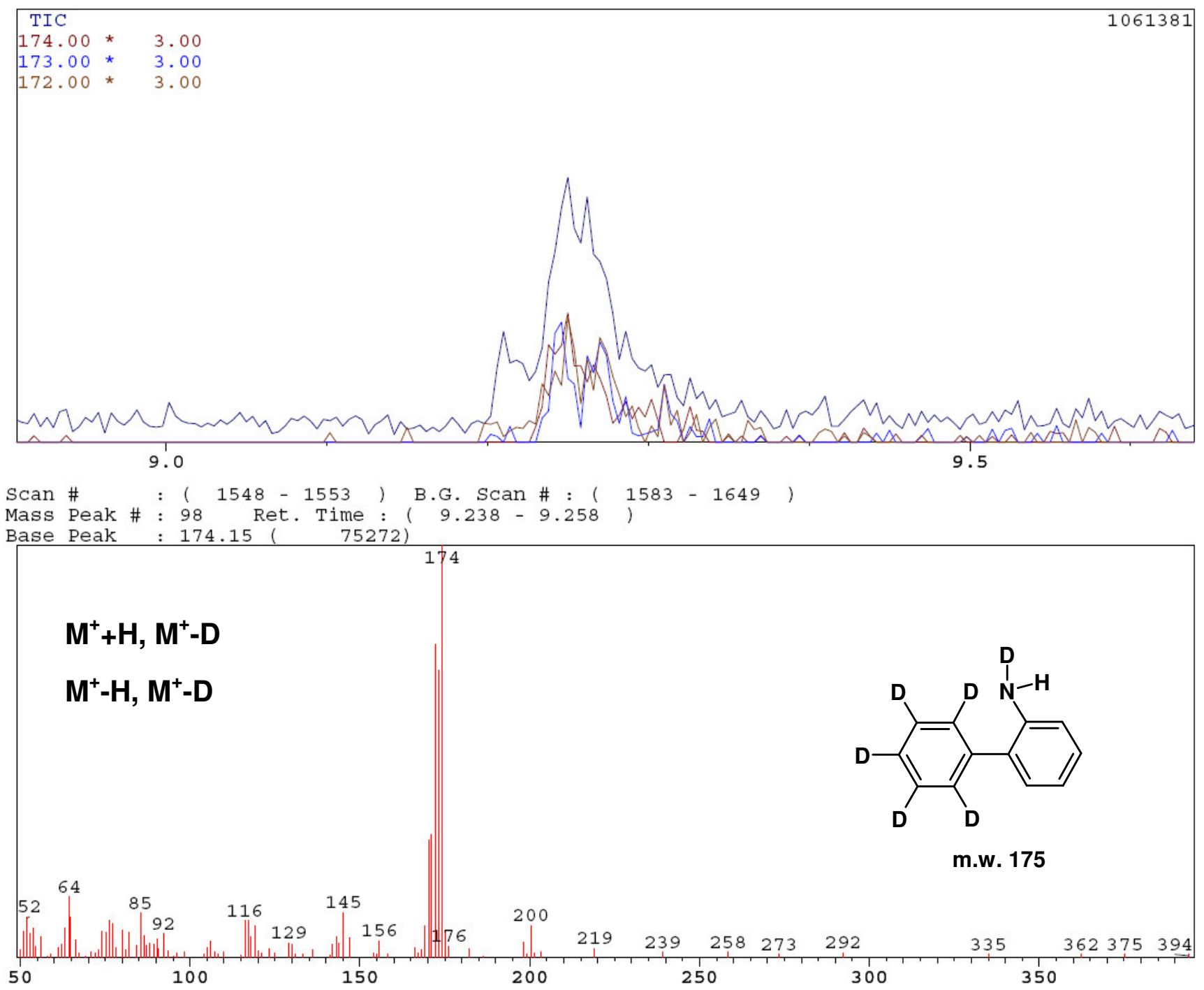




\section{MS of intermediate"imine"-d5 (2').}
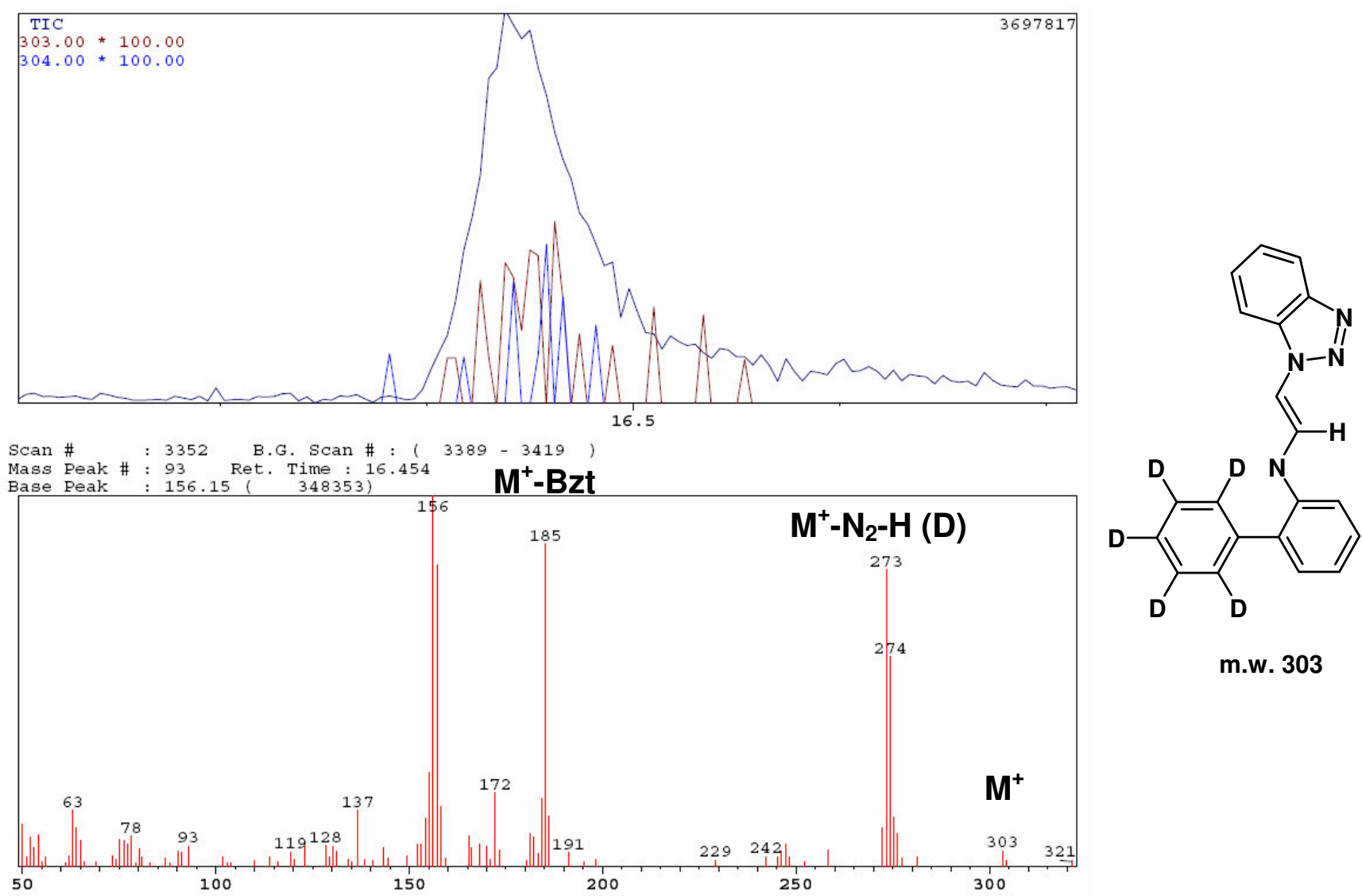

m.w. 303 


\section{MS of phenantridine- $d 4$ (3').}

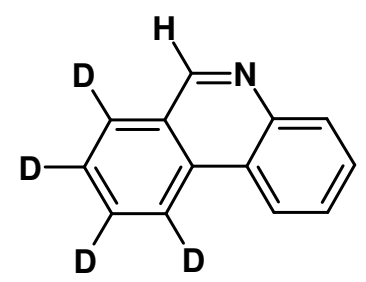

m.w. 183

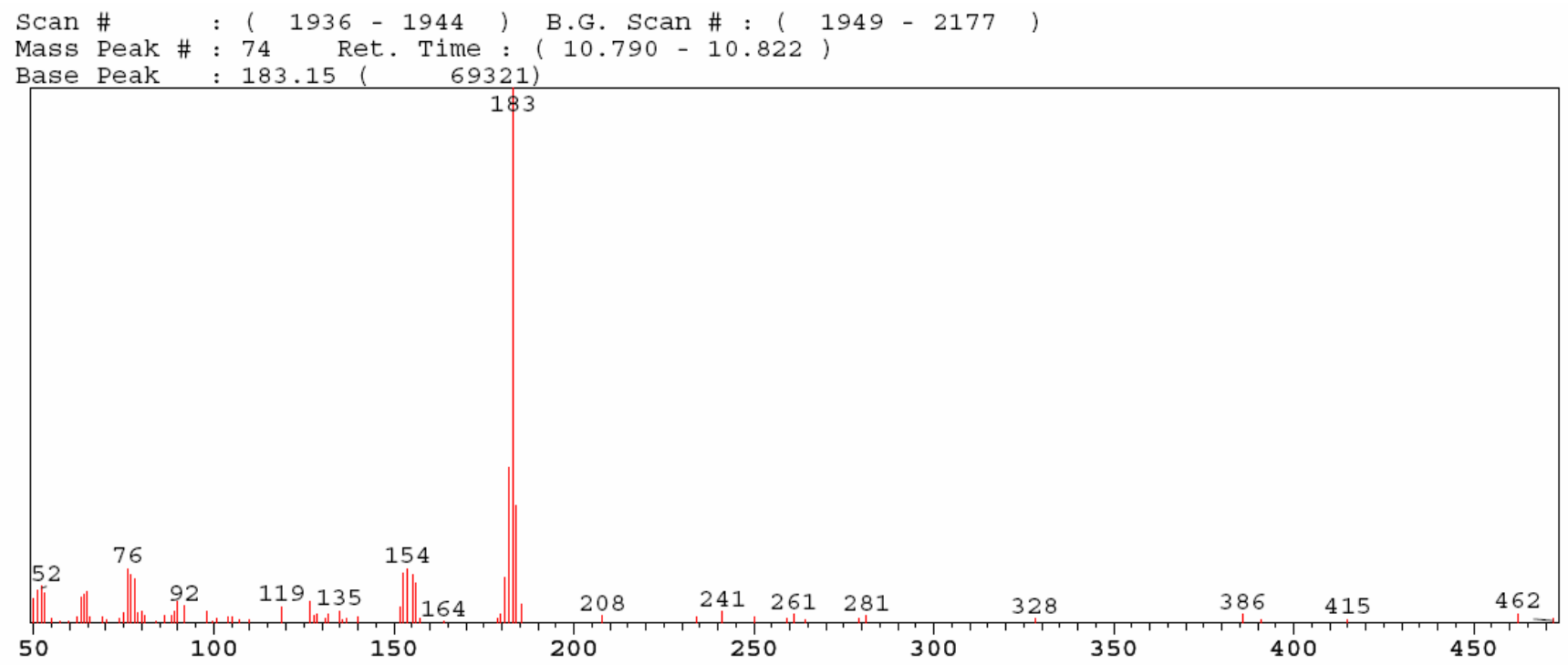


UV spectra of tris(1-benzotriazolyl)methane (1) and products of its photodecomposition in cyclohexane.

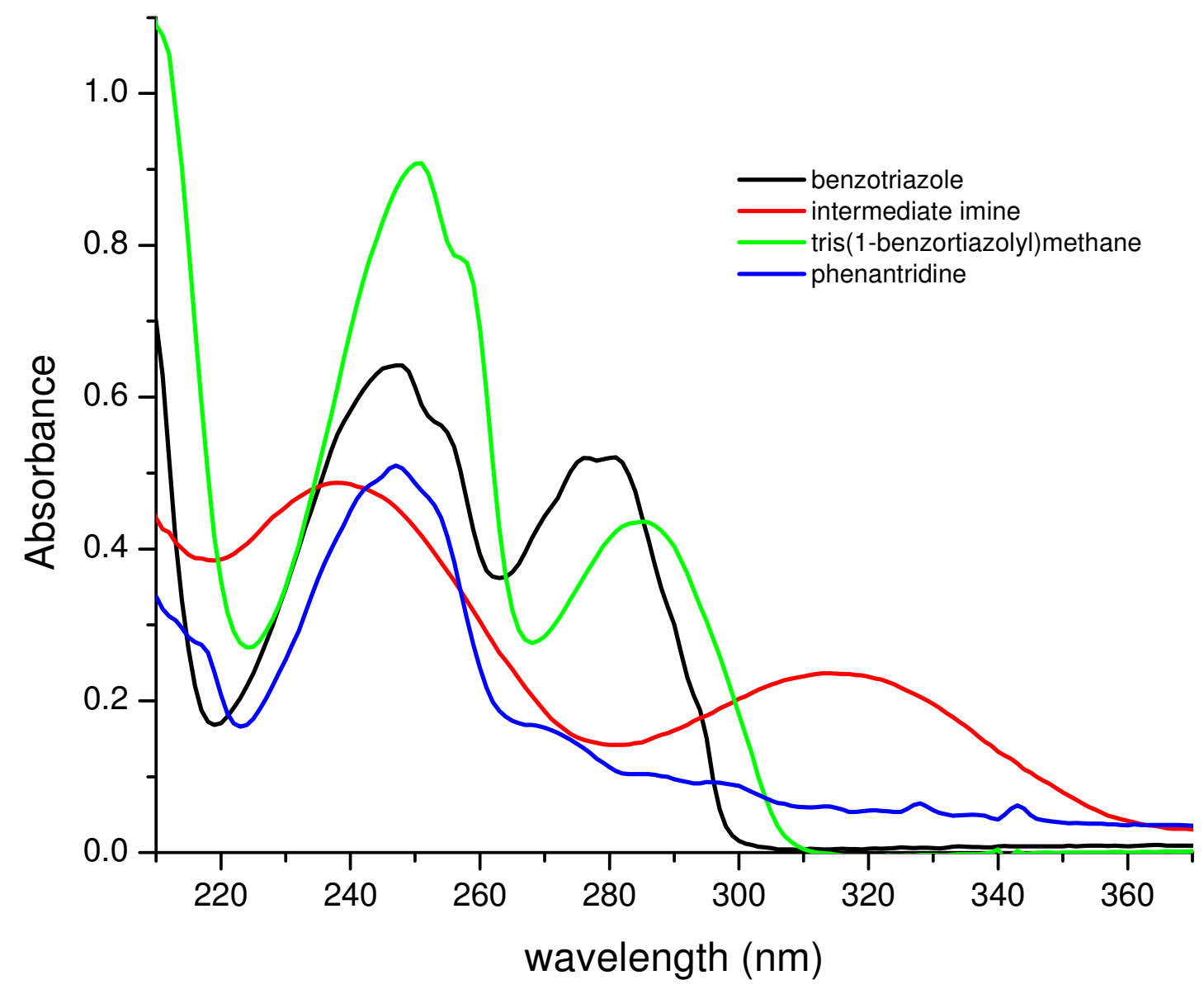


${ }^{1}$ H-NMR monitoring of tris(1-benzotriazolyl)methane (1) photodecomposition in $\mathrm{C}_{6} \mathrm{D}_{6}\left(\mathrm{C}_{0}=4.09 \times 10^{-3} \mathrm{~mol} / \mathrm{l}\right)$ at $\lambda=254 \mathrm{~nm}$.

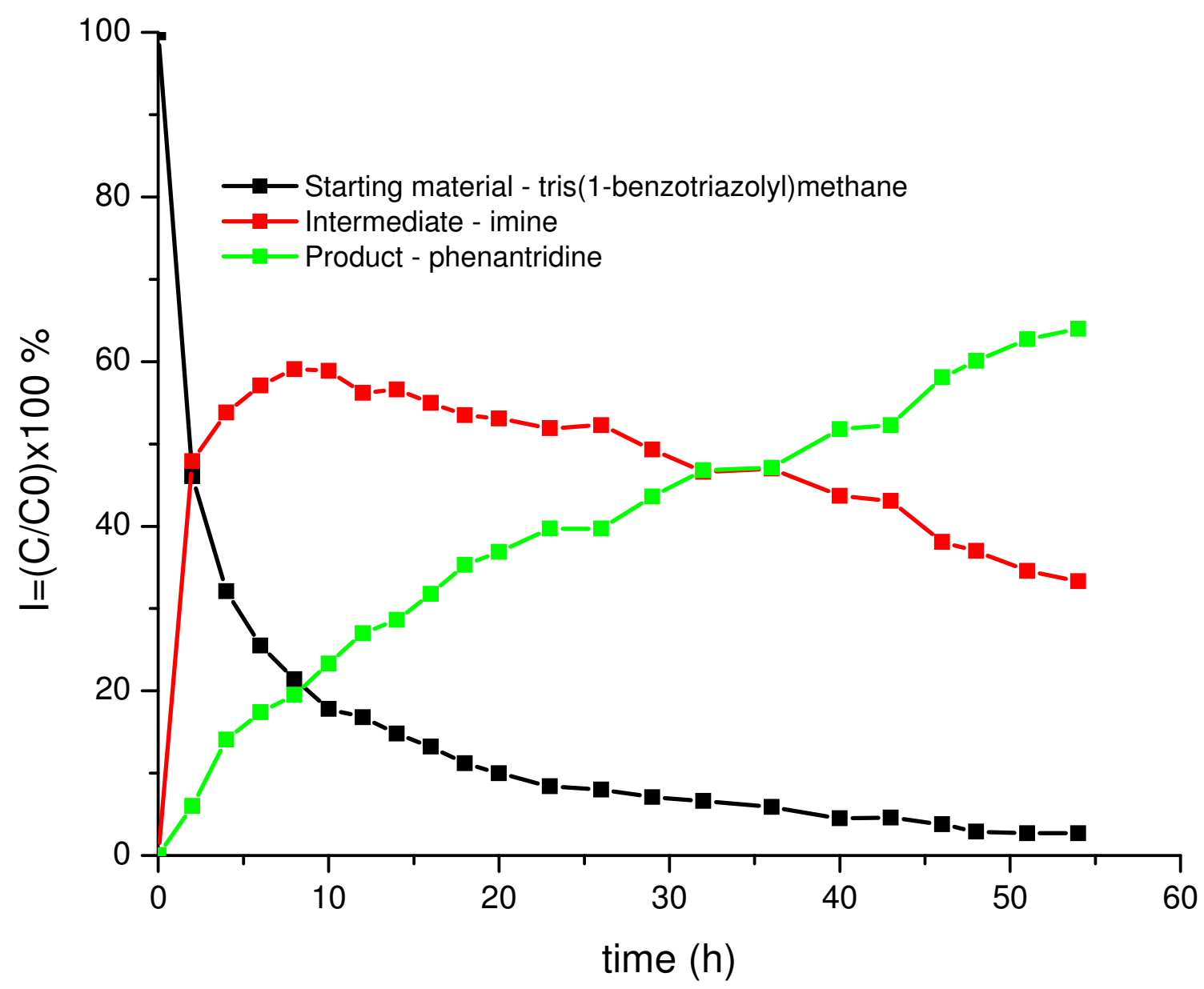

$8.70 \mathrm{ppm}$<smiles></smiles>

$9.13 \mathrm{ppm}$<smiles>c1ccc2c(c1)cnc1ccccc12</smiles> 

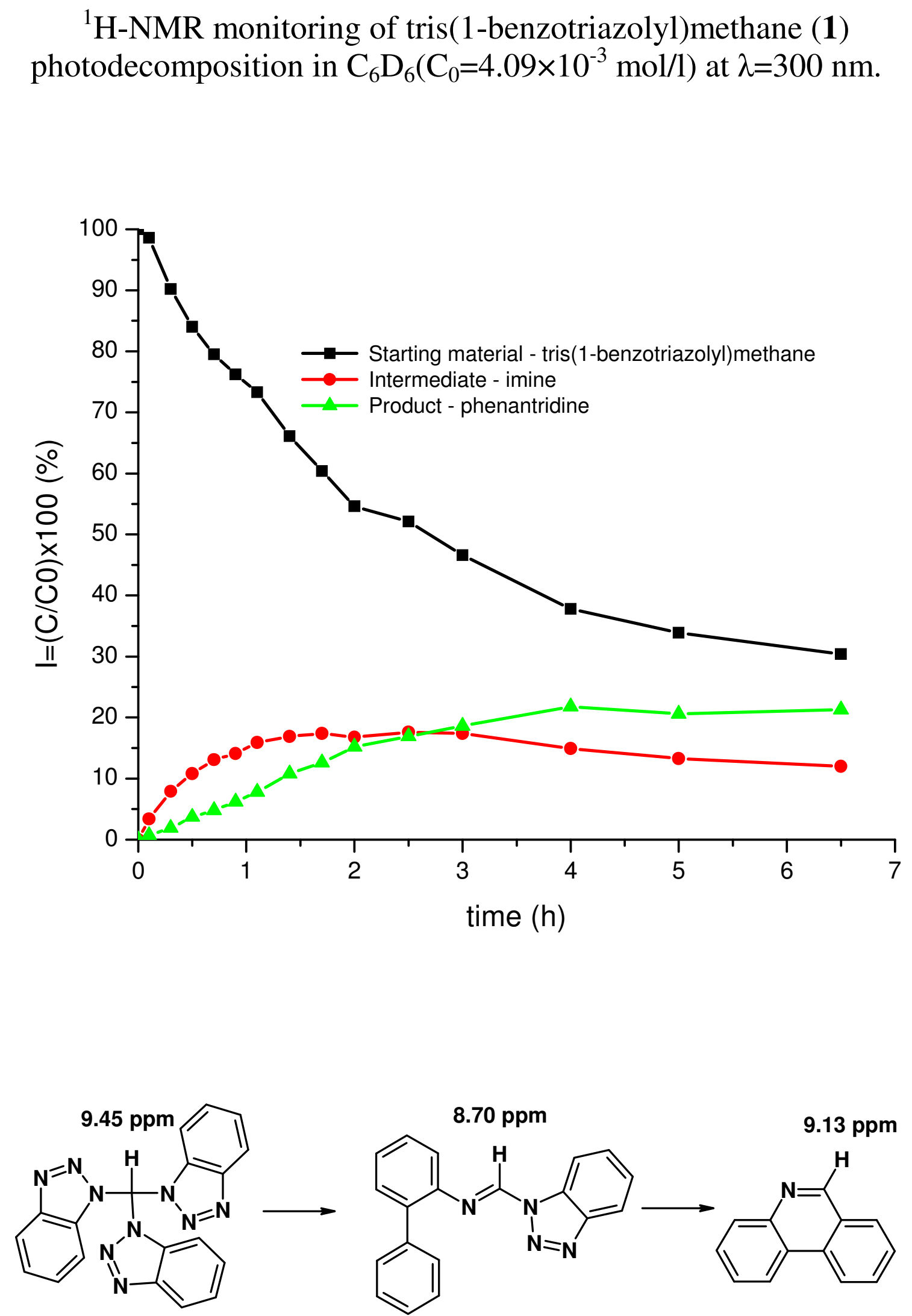
UV spectra of tris-(1-benzotriazolyl)methane (1) and benzotriazole (4) in methanol.

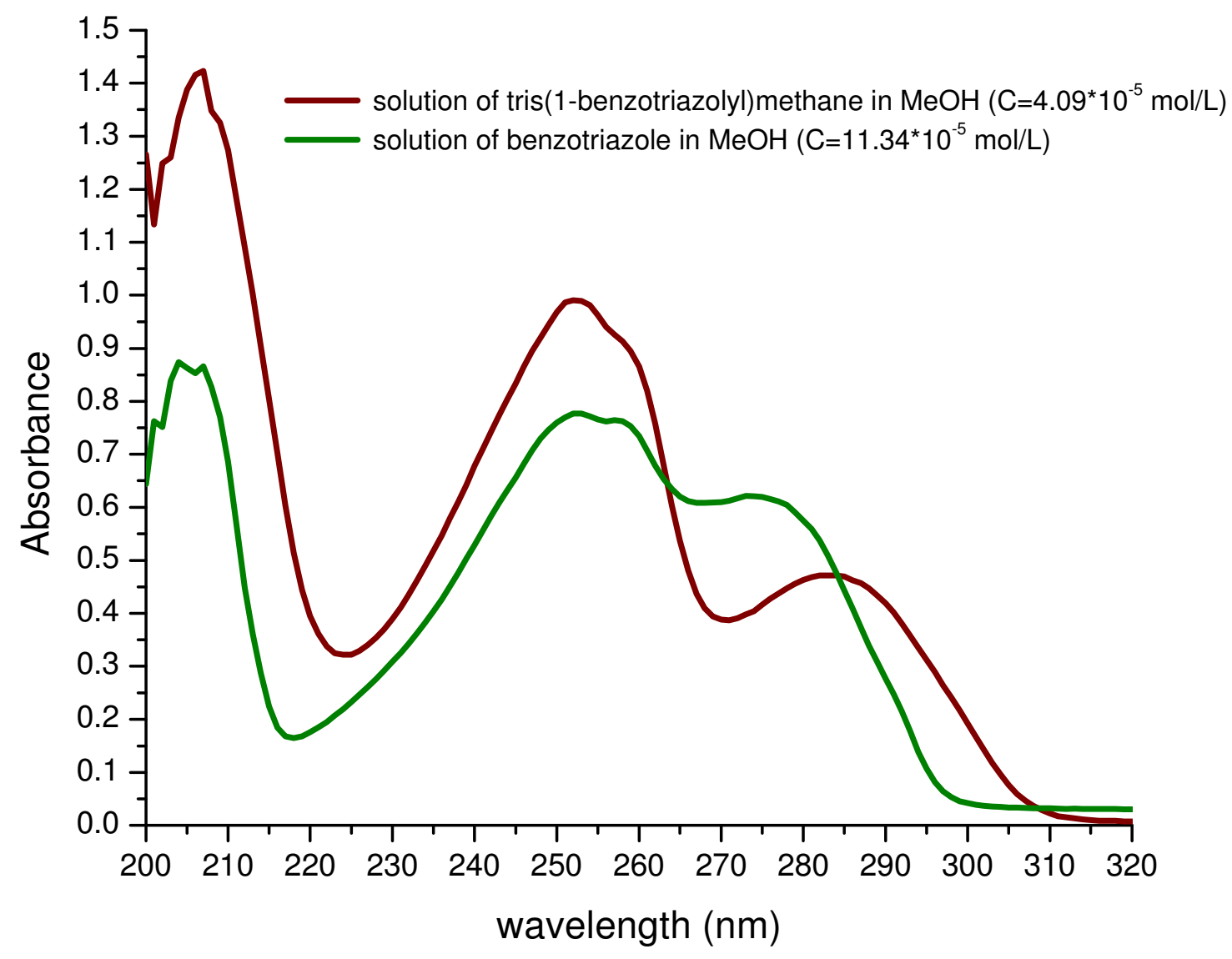


Irradiation of tris(1-benzotriazolyl)methane in methanol at $300 \mathrm{~nm}$.

UV monitoring.

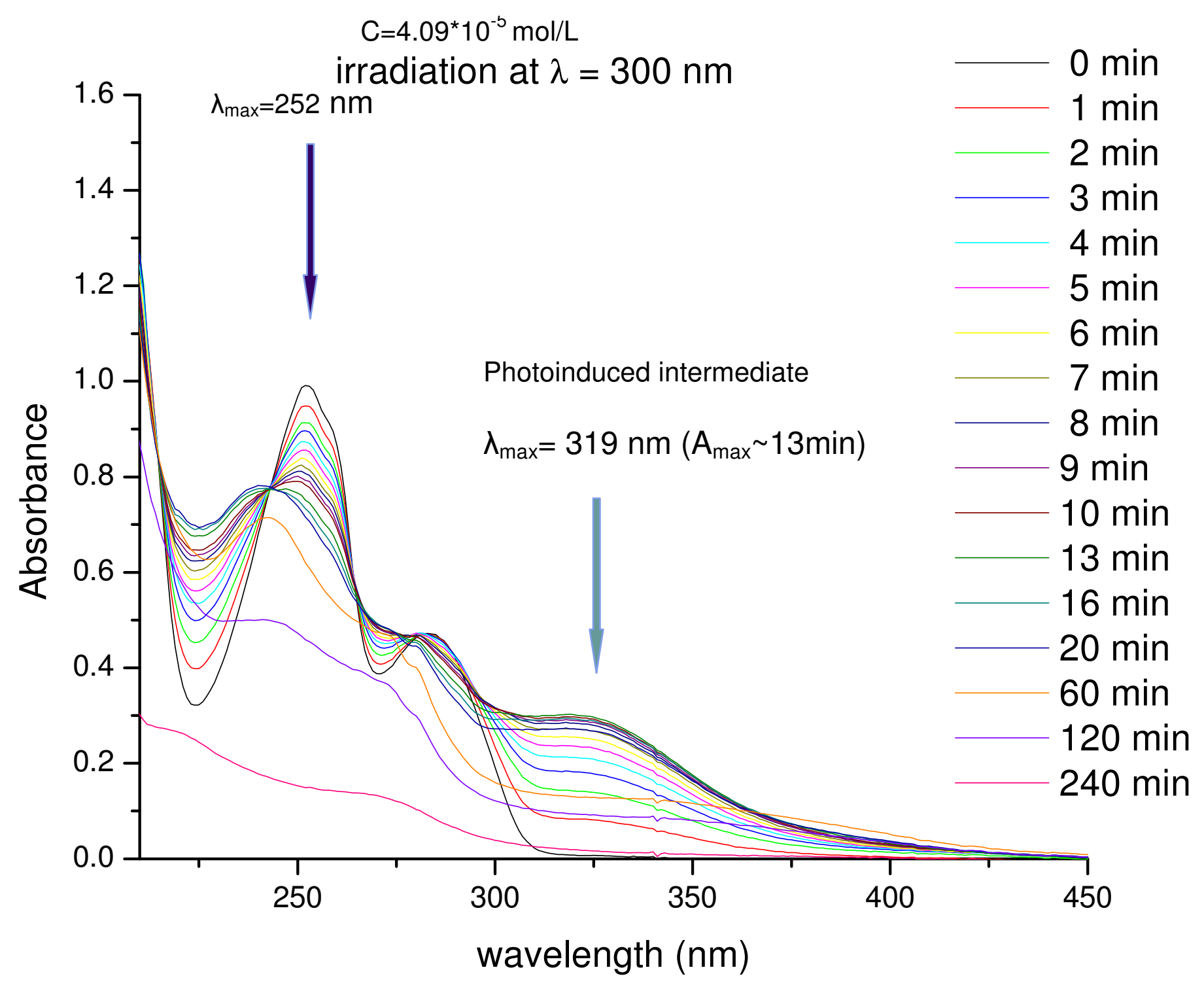




\section{Irradiation of tris(1-benzotriazolyl)methane (1) ethanol at $254 \mathrm{~nm}$.}

UV monitoring.

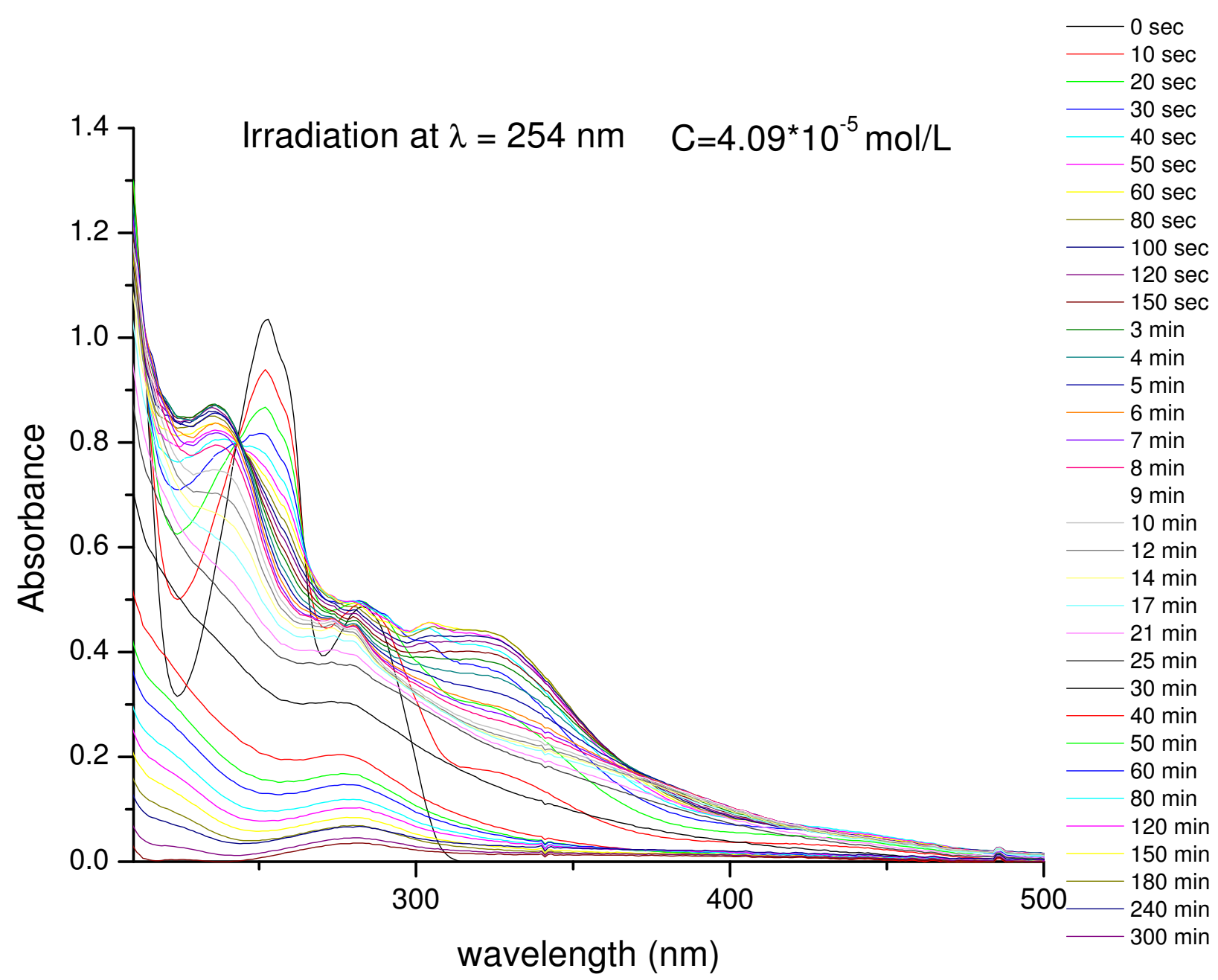

-S32- 


\section{General methods and materials.}

Reagents. All chemicals were used as purchased. Solvents for crystallization and chromatography were of technical grade. When required, solvents were freshly distilled from appropriate drying agents before use.

General Methods. Analytical TLC was performed with silica gel $60 \mathrm{~F}_{254}$ plates. Melting points are uncorrected. UV absorption spectra were recorded on a UV-visible spectrophotometer, using $1 \times 1 \mathrm{~cm}$ quartz cells. Mass spectra were obtained on a triple quadrupole mass spectrometer by electron ionization (EI) at $70 \mathrm{eV}$. High-resolution mass spectra were recorded on a double focusing magnetic sector mass spectrometer using using EI at $70 \mathrm{eV} .{ }^{1} \mathrm{H}$ and ${ }^{13} \mathrm{C}$ NMR spectra were recorded at 300 and $75 \mathrm{MHz}$ respectively, in $\mathrm{CDCl}_{3}, \mathrm{C}_{6} \mathrm{D}_{6}$, and $\mathrm{CD}_{3} \mathrm{OD}$ using TMS $(\delta=0.0 \mathrm{ppm})$ or the signal of residual solvent protons as an internal standard.

GC-MS analyses were carried out using a gas chromatograph with a series mass selective detector (EI, $70 \mathrm{eV}$ ), using a capillary column with $25 \mathrm{~m}$ length and $0.25 \mathrm{~mm}$ I.D. The initial temperature of $70{ }^{\circ} \mathrm{C}$ was maintained for $3 \mathrm{~min}$ and then a heating rate of $20^{\circ} \mathrm{C} / \mathrm{min}$ was applied until a final temperature of $270{ }^{\circ} \mathrm{C}$ was reached.

Photoirradiation. Photodegradation studies were conducted in a Rayonet photoreactor RPR-100

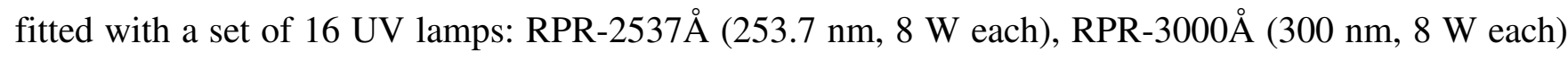
or F8T5BLB (365 nm, $8 \mathrm{~W}$ each). Operating temperature was $30-35{ }^{\circ} \mathrm{C}$. The solutions of the irradiated substances in a quartz NMR tube, $1 \times 1 \mathrm{~cm}$ quartz cell or a quarts vessel (length 10 ", diameter 1.5")

positioned in the center of photoreactor. Generally, $10^{-4} \mathrm{M}$ starting solutions were used when the analysis was carried out by HPLC. More concentrated $10^{-2} \mathrm{M}$ solutions were used for product identification using GC-MS. 